\title{
8. PHOSPHATIC SEDIMENTS AND ROCKS RECOVERED FROM THE PERU MARGIN DURING ODP LEG $112^{1}$
}

\author{
Robert E. Garrison ${ }^{2}$ and Miriam Kastner ${ }^{3}$
}

\begin{abstract}
Coring during Ocean Drilling Program (ODP) Leg 112 recovered phosphatic materials from six sites in forearc basins on the shelf and upper slope west of Peru. Three types of phosphates occur. F-phosphates are friable, light colored micronodules and peloids of carbonate fluorapatite (CFA); these formed by precipitation of CFA in laminated diatom muds deposited within the oxygen-minimum zone. Phosphatic sands, termed P-phosphates, consist of phosphatic peloids, coated grains, and fish debris, often having an admixture of fine siliciclastic grains. These sands occur in thin layers and burrowed beds up to $2 \mathrm{~m}$ thick; they may record high energy conditions and, in places, they occur above unconformities. Most abundant are dark and dense phosphates, herein called D-phosphates, that occur as nodules, gravels, and hardgrounds. These phosphates formed through complicated cycles of CFA precipitation during early diagenesis, erosion and exhumation, and reburial and rephosphatization processes associated with changing energy conditions that may reflect the effects of changes in sea level on the Peru shelf. CFA cements in P-and D-phosphates often replaced microbial structures, but our data do not reveal whether this microbial involvement was passive or active. The three phosphate types record a time and energy spectrum, with F-phosphates at the lower end, D-phosphates at the upper.

Phosphates along the Peru margin occur in sediments as old as middle Miocene but are most abundant in Pliocene and especially Quaternary upwelling sediments. F-phosphates are most common in deeper water, outer-shelf/upper-slope sites, whereas D- and P-phosphates tend to predominate at shallower shelf sites more subject to episodic high energy conditions, especially during lowstands of sea level. Although lowstands of sea level probably led to concentration of phosphatic particles by winnowing, most CFA precipitation and cementation may have occurred, at least during Quaternary time, during interglacial highstands.
\end{abstract}

\section{INTRODUCTION}

Frequently cited as a modern analog for ancient upwelling sequences in the geologic record, the organic- and diatom-rich sediments of the Peru margin are also the site of contemporary phosphogenesis. Consequently, this region has often been proposed as a modern model useful for explaining the large, economically significant phosphorite deposits in the geologic record, with the implicit assumption that such deposits are in some manner the products of upwelling.

For this reason, considerable research has focused in this area, and, over the past two decades, dredging and coring recovered phosphatic materials in Quaternary sediments of the continental shelf and upper slope west of Peru. Study of these materials and associated pore waters was instrumental in advancing our knowledge of phosphogenesis (Baturin et al., 1972; Burnett, 1977; Burnett and Froelich, 1988a), but samples could only be collected from near the seafloor by the methods mentioned above. As noted by Burnett and Froelich (1988b), the limitations of this sampling raise questions about the analogies made between Peru margin phosphates and many of the large phosphorite deposits of the geologic record, a skepticism voiced also by Bentor (1980).

Coring during Leg 112 allowed us to examine the deeper and older record of phosphogenesis and permits us to study phosphatic layers in their stratigraphic context, as reported here. Figures 1 and 2 and Table 1 portray the geographic and stratigraphic occurrences of phosphates recovered during Leg

\footnotetext{
${ }^{1}$ Suess, E., von Huene, R., et al., 1990. Proc. ODP, Sci. Results, 112: College Station, TX (Ocean Drilling Program).

2 Earth Sciences Board, University of California, Santa Cruz, CA 95064.

${ }^{3}$ Geological Research Division, Scripps Institution of Oceanography, La Jolla, CA 92093.
}

112. The phosphate-bearing sites occur within the present oxygen-minimum zone in forearc basins on the shelf and upper slope (Sites 679, 680,681, 684, 686, and 687). No phosphates were recovered from most of the deeper slope sites $(682,683$, and 685$)$; the one exception is Site 688 , which contains minor phosphatic sediment, but this occurs either in slumped blocks of shelf/upper-slope sediment or as sparse grains in turbiditic sand redeposited from the shelf. The marked thickness variations of age-equivalent intervals shown in Figure 2 reflect substantial differences in subsidence rates among the forearc basins; for example, slow subsidence in the Trujillo Basin (Site 684) resulted in considerable winnowing and a thin Quaternary sequence, whereas the thick Quaternary succession in the West Pisco Basin (Site 686) reflects rapid subsidence.

\section{METHODS}

Standard analyses of thin sections were performed for 193 samples, including many friable samples that required vacuum-impregnation, and scanning electron microscope studies (utilizing an International Scientific Instruments WB-6 scanning electron microscope) were made of 33 samples that were sputter-coated with a gold-palladium alloy.

\section{PREVIOUS WORK ON PERUVIAN MARGIN PHOSPHORITES}

Confirmation that phosphogenesis in sediments beneath upwelling zones of the Peru margin occurred during late Quaternary time emerged through application of uraniumseries disequilibrium dating by Baturin et al. (1972), Veeh et al. (1973), Burnett and Veeh (1977), and Burnett $(1977,1980)$. These scientists established an early diagenetic origin for phosphorites, both on the seafloor (Burnett et al., 1982) and in anoxic pore waters just beneath the sediment/water interface 


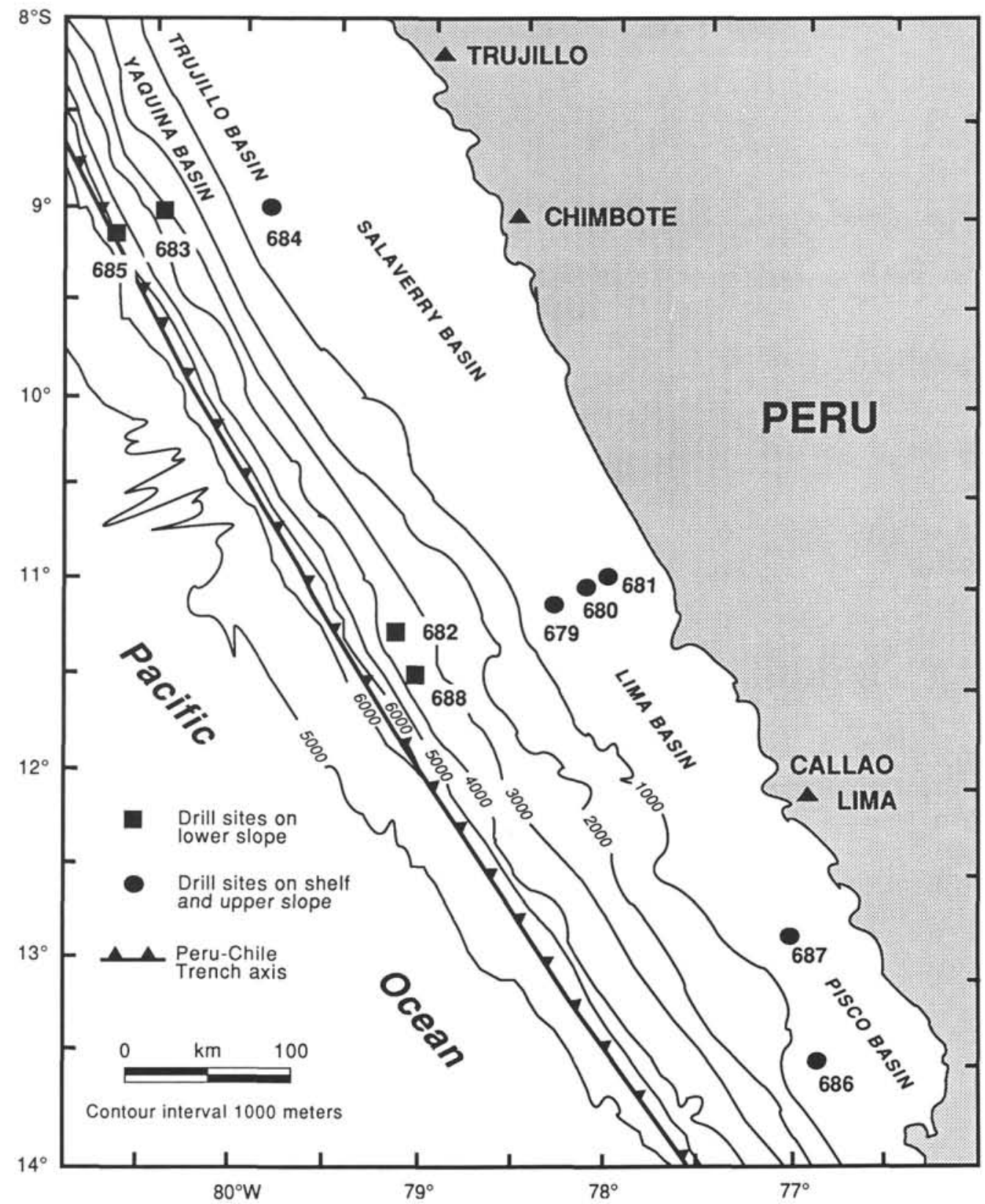

Figure 1. Leg 112 drill sites (679 through 688); bathymetry is in meters. Phosphatic sediments and rocks were recovered only at shelf and upper-slope Sites 679, 680, 681, 684, 686, and 687 (map from Suess, von Huene, et al., 1988; modified from Thornburg and Kulm, 1981).

(Burnett, 1977; see also Atlas, 1975) through precipitation of CFA in pore spaces (Burnett, 1977) and replacement of biogenic calcium carbonate (Manheim et al., 1975; Burnett, 1977). Fluoride pore-water profiles from phosphorite areas of Peru also support the notion of an early diagenetic origin (Froelich et al., 1983); these profiles suggest that fluoride diffusion from seawater is critical to the formation of CFA and hence may limit phosphogenesis to areas of low sedimentation rates or nonsedimentation.

Burnett (1977) and subsequent scientists proposed that the major source of phosphorus for CFA precipitation was decomposition of planktonic organic matter in anoxic pore waters. However, in some late Quaternary Peru margin phosphatic sediments, on the basis of pore-water phosphorus concentrations in excess of the amount calculated from or- ganic matter stoichiometry, Suess (1981) concluded that fish debris is quantitatively a more significant phosphorus source for apatites. This idea was supported by a recent study by Van Cappellan and Berner (1988). By modeling pore-water phosphorus and fluoride profiles, they also concluded that fish debris may be an important source of phosphorus for the origin of the Holocene apatite in continental margin sediments off western Mexico (Jahnke et al., 1983). New chemical and mineralogical analyses of the apatite-bearing Mexican margin sediments (Schuffert et al., 1987) and preliminary results from modeling pore-water profiles suggest that two other plausible phosphorus sources for the Holocene apatite in this region may be either from an iron redox cycle phosphate pump (previously described by Shaffer, 1986; Heggie et al., 1987; O'Brien and Heggie, 1988; and Froelich et al., 1988) or from 


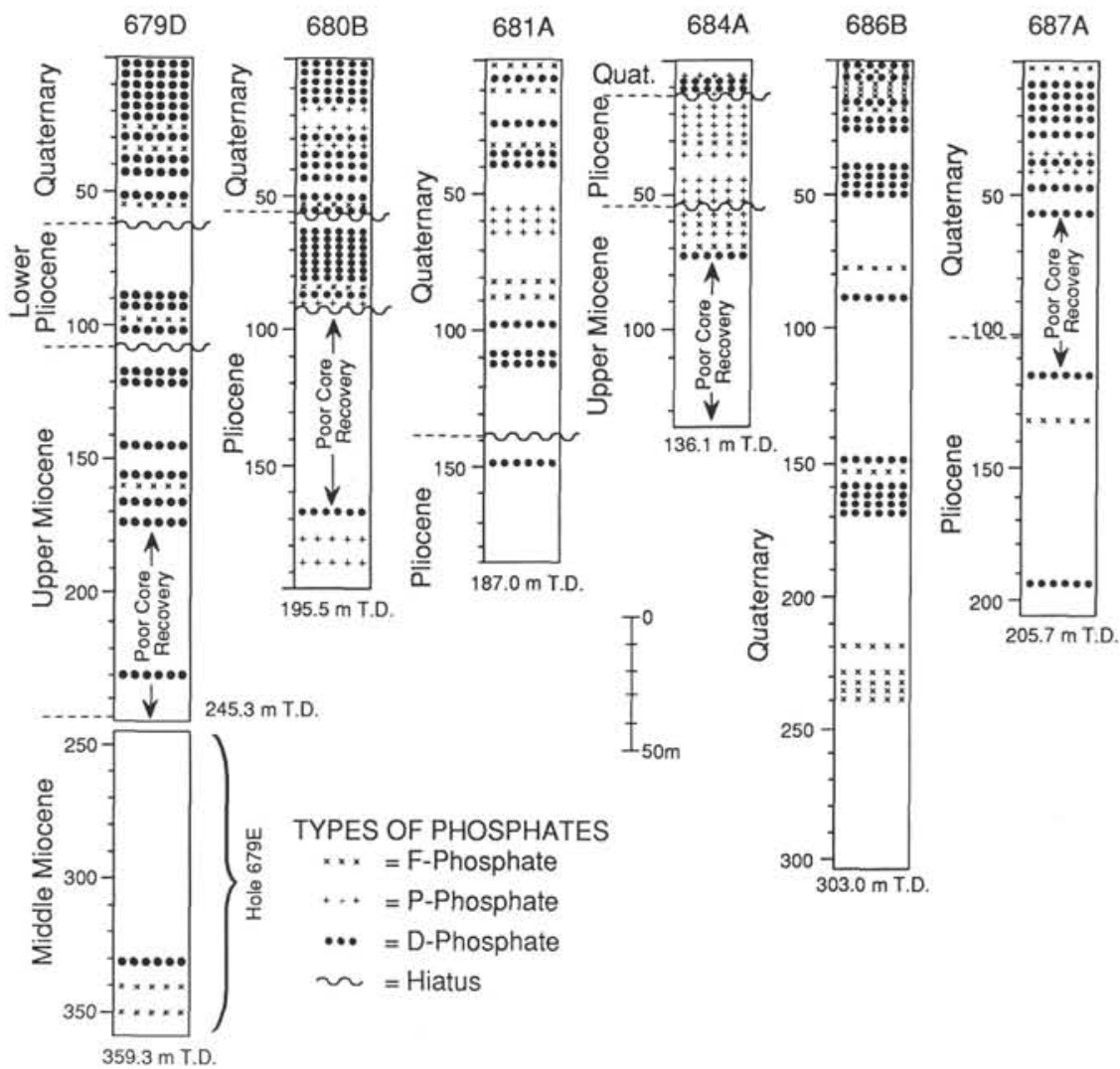

Figure 2. Stratigraphic sections from Leg 112 holes drilled at the six shelf and upper-slope sites, showing the distribution of phosphatic sediment types recovered. Total depths (T.D.) are in meters below the seafloor (mbsf). Holes 679D and $679 \mathrm{E}$ are shown as a composite. See Figure 1 for locations.

molecular diffusion of dissolved phosphorus from seawater controlled by sedimentation rates (Schuffert, Kastner and Jahnke, unpublished data).

Burnett et al (1980) were the first to establish a relationship between Peru margin phosphates and the oxygen-minimum zone, noting a concentration of nodules and slabs (herein called D-phosphates) near the boundaries of the present oxygen-minimum zone. Burnett (1980) also called attention to finely crystalline phosphates (which he termed "collophane mudstones," herein called F-phosphates) in the oxygen-minimum zone as well as occurrences of pelletal phosphatic and glauconitic sands near its lower boundary. Growth rates for both nodules and pellets from the Peru margin were calculated by uranium-series and carbon-14 dating. Some nodules grow more slowly than the sedimentation rates of the enclosing sediment; thus, they should be quickly buried beneath the reactive zone near the seafloor, unless they are maintained in this zone by burrowing organisms or winnowing (Burnett, 1980; Burnett et al.,1982). In contrast, phosphatic pellets may form more rapidly, in as little as 10 years or less after growth is initiated (Burnett et al.,1988).

Additional research on Peru margin phosphate pellets by Kim and Burnett (1988) and Baker and Burnett (1988) led these authors to conclude that pelletal layers of Quaternary age show biological, but not mechanical, mixing; thus they considered that extensive winnowing during deposition of these pellets was unlikely. Glenn and Arthur (1988a), on the basis of substantial petrological and solid-phase geochemical studies, established a paragenetic sequence for Peru margin diagenetic products, including glauconite, apatite, pyrite and dolomite, all of which can be shown to form within a few
Table 1. Age distribution of different varieties of phosphorites recovered from the Peru margin during Leg 112.

\begin{tabular}{|c|c|c|c|c|}
\hline Site & $\begin{array}{l}\text { Modern water } \\
\text { depth (mbsf) }\end{array}$ & Quaternary & Pliocene & $\begin{array}{l}\text { Miocene } \\
\text { Quaternary }\end{array}$ \\
\hline 679 & 450 & F, D & F, D & F, D \\
\hline 680 & 252 & $\mathrm{D}, \mathrm{F}, \mathrm{P}$ & F, P, D & Not sampled \\
\hline 681 & 150 & $\begin{array}{l}\mathrm{D}, \mathrm{P}, \\
\text { minor } \mathrm{F}\end{array}$ & D & Not sampled \\
\hline 684 & 426 & $\begin{array}{l}\mathrm{D}, \mathrm{P} \text {, } \\
\text { minor F }\end{array}$ & P, F, D & Minor $\mathrm{D}$ and $\mathrm{F}$ \\
\hline 686 & 447 & F, D & Not sampled & Not sampled \\
\hline 687 & 307 & $\mathrm{D}$, minor $\mathrm{F}$ & Minor D & Not sampled \\
\hline 688 & 3826 & None & None & ${ }^{\mathrm{a}}$ Minor $\mathrm{D}$ and $\mathrm{F}$ \\
\hline
\end{tabular}

a Probably transported from shelf depths by slumping and redeposition. $\mathrm{F}=$ F-phosphorites, $\mathrm{P}=$ peloidal phosphiritic sands, $\mathrm{D}=\mathrm{D}$-phosphorites (see text for definitions); these are listed in order of abundance.

centimeters below the seafloor (a view supported by Glenn et al.'s [1988] isotopic and pore water studies).

\section{TYPES OF RECOVERED PHOSPHORITES AND PHOSPHATIC SEDIMENTS}

Three distinctive types of phosphatic materials were recovered in Leg 112 cores:

1. F-phosphate: small nodules, peloids and laminae of friable, light-colored CFA in diatomaceous muds.

2. P-phosphates: phosphoritic sands dominated by phosphatic peloids, but also containing coated grains as well as fish bones and teeth. 
3. D-phosphates: well-lithified, often dark and dense nodules, gravels, and hardgrounds of CFA.

\section{F-Phosphates}

\section{General Characteristics}

F-phosphates are sand-size peloids, micronodules (typically small ellipsoidal nodules elongated parallel to bedding, having diameters of 0.5 to $2.0 \mathrm{~cm}$.), and laminae of cryptocrystalline CFA that occur within diatom muds (Figs. 3 through 5). These phosphates may be the same type of phosphate that Burnett (1980) called "collophane mudstones." Color varies from cream to light yellow brown, pink brown, and brown, and, in the more mature varieties (see below), a darkened thin rim at the margins of the micronodules commonly occurs. Consistency varies from very friable and unconsolidated (cf. Fig. 3) to more compact, though even the latter are porous, soft, and can be scratched with the fingernail. As the micronodules and peloids become denser and more consolidated, they undergo a transition from bodies with irregular, somewhat diffuse boundaries to bodies with sharply defined edges (Figs. 6 and 7). As F-phosphate micronodules become denser, they also have a tendency to become slightly darker, and some of the densest micronodules have thin, darkened rims. Presumably, these changes reflect a maturation sequence marked by increasing precipitation of CFA.

\section{Petrography of F-Phosphates}

Petrographic observations show that the micronodules and peloids enclose well-preserved diatoms and, more rarely, foraminiferal tests and silt-size siliciclastic grains (Figs. 6 through 8). The F-phosphate bodies thus grew within the enclosing diatom muds, incorporating as well as replacing some of the host sediment. CFA globular structures in friable F-micronodules (Fig. 8) closely resemble phosphatized bacterial cells in Holocene phosphorites from the East Australian margin (O'Brien et al., 1981) and in similar friable phosphates from the Miocene Monterey Formation of California (Garrison et al., 1987). Laminae that show compactional bending around micronodules (usually the dense, mature variety having sharp edges, cf. Figs. 6 and 7) as well as fish bones that are bent or broken against the margins of micronodules indicate that some micronodules were rigid bodies in the pre-compaction stages of diagenesis. F-peloids and micronodules often occur enclosed within and partly replaced by finely crystalline dolomite, evidence for phosphatization, which proceeded dolomitization.

\section{Origin and Distribution of F-Phosphates}

The most common host sediment for F-phosphates is detritus-poor, laminated diatom mud (best seen at Site 684); within such sediments, F-phosphates often, but not inevitably, occur in layers that contain abundant large foraminiferal tests and appear somewhat winnowed. These characteristics suggest F-phosphates formed by localized precipitation of CFA in organic-rich muds during periods of reduced sedimentation, the latter brought about by reduced detrital influx and/or winnowing by weak bottom currents. F-phosphatic laminations (Fig. 5) formed by lateral growth and coalescence of peloids and micronodules, possibly the consequence of prolonged periods of slow sedimentation or nonsedimentation. A few F-micronodules are present in massive, burrowed diatom muds that were later burrowed when oxygen levels at the seafloor changed to permit colonization by macro-organisms.

An early diagenetic origin for F-phosphates is indicated by (1) their occurrence in Holocene sediments at shallow subbottom depths (e.g., 1.9 mbsf at Site 687, 3.03 mbsf at Site

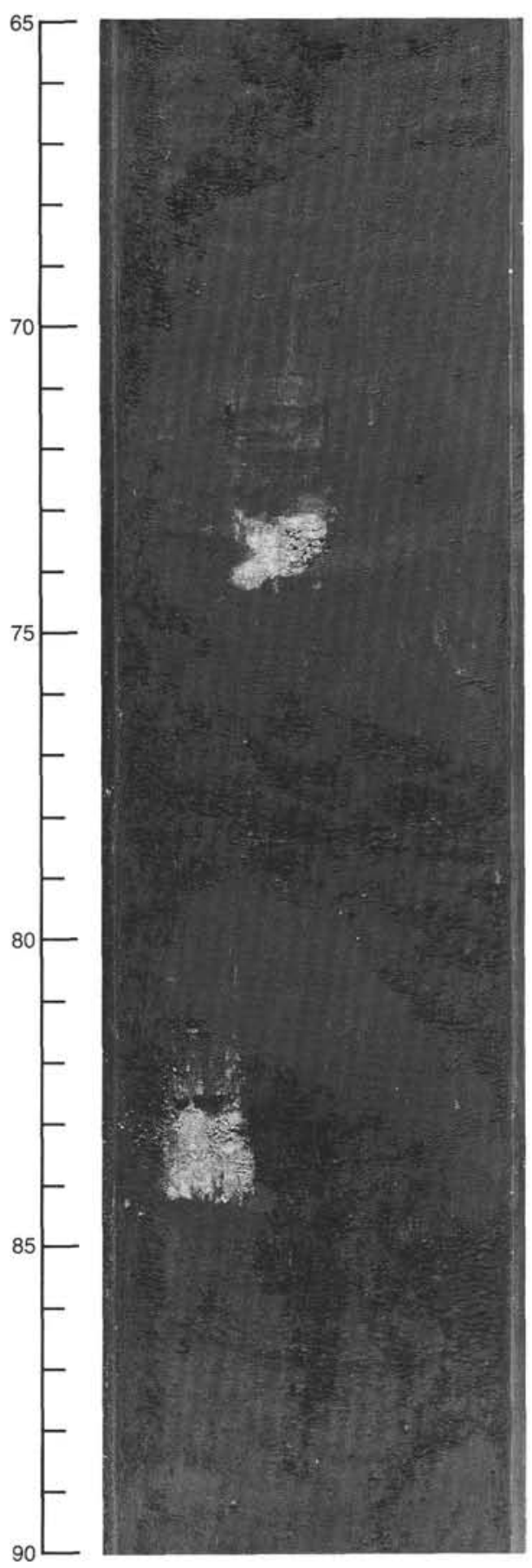

Figure 3. Superimposed in this core segment are two different types of phosphate. The two light-colored patches are F-phosphate nodules; their weak induration is indicated by the smearing of powdery white CFA along the cut surface of the core. The host sediment is middle or upper Miocene burrowed diatomaceous mud. The dark granular sediment filling burrows is phosphatic-glauconitic sand (P-phosphate) of probable Pliocene age (cf. Figs. 1 and 12; interval 112-684-7H-3, $65-90 \mathrm{~cm})$.

$681)$; (2) the presence of rotated F-micronodules in a soft sediment slump fold at Site 686 , showing that they formed prior to folding; and (3) as noted above, their inclusion in and replacement by authigenic dolomite and evidence for precompaction phosphogenesis. Based on core and dredge samples, Burnett (1980) indicated that this kind of phosphate 


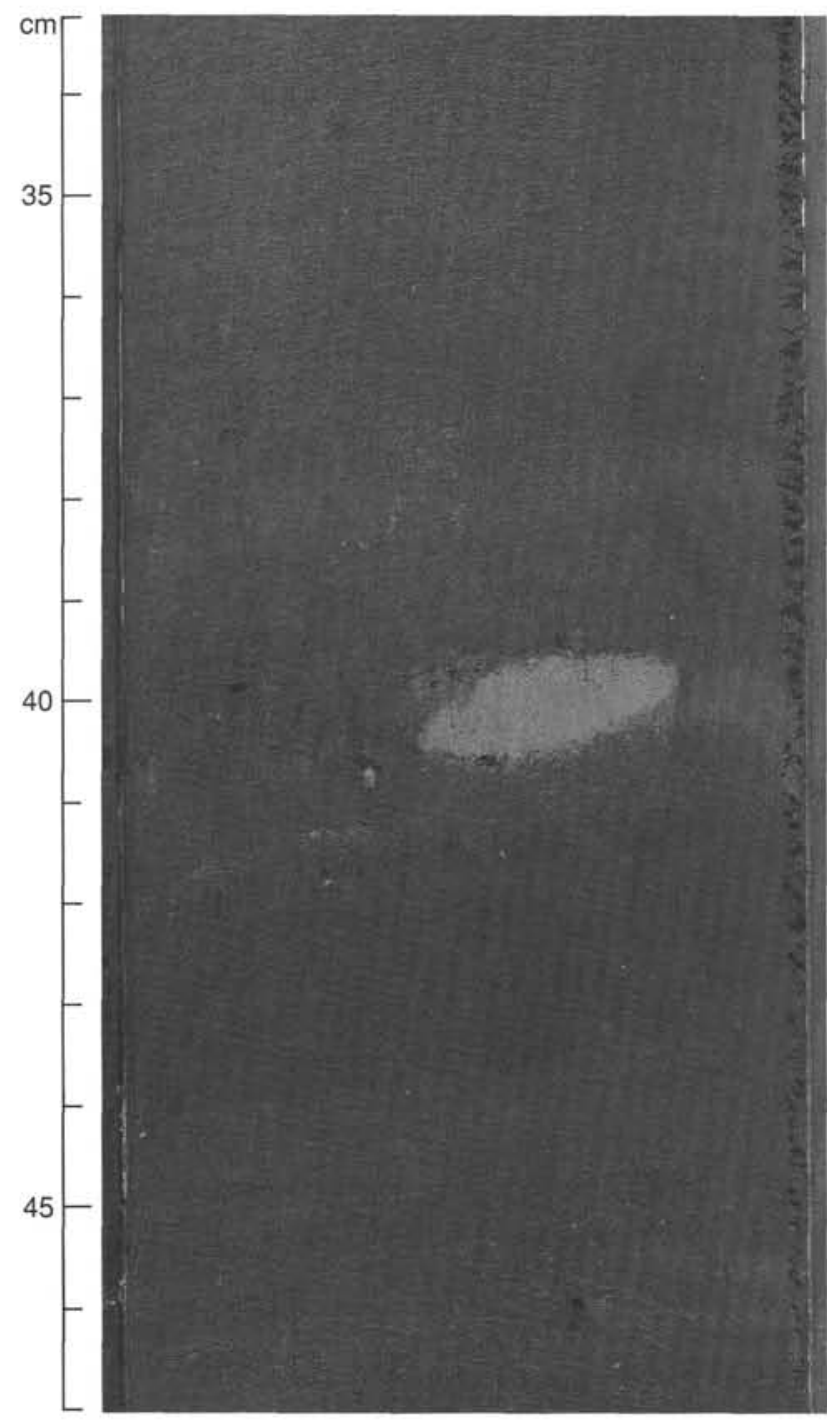

Figure 4. Small F-phosphate nodule in banded diatomaceous mud of Pliocene age (112-680A-10H-6, 33-47 cm).

("collophane mudstone") is most abundant in Quaternary muds, where the oxygen-minimum zone intersects the outer shelf and upper slope off Peru and Chile. Lending support to this interpretation is the abundance in Leg 112 cores of F-phosphates in laminated, unburrowed diatom muds.

F-phosphates are present in middle Miocene to Quaternary diatom muds at all six shelf and upper-slope sites (Fig. 2 and Table 1). These phosphates are most abundant, however, in Quaternary muds of the deeper water outer-shelf/upper-slope sites $(679,680$, and 886$)$.

\section{P-Phosphates}

\section{General Characteristics}

P-phosphates are medium- to coarse-grained, well-sorted, unlithified sands in which phosphate grains are the dominant or only component. P-phosphatic sands are gradational to dominantly siliciclastic sands that may have only a minor component of phosphatic grains. Some P-sands, particularly at Site 684 , contain abundant glauconite grains and foraminiferal tests. P-phosphatic sands may contain scattered reworked D-phosphate nodules or bone fragments (Fig. 10), or

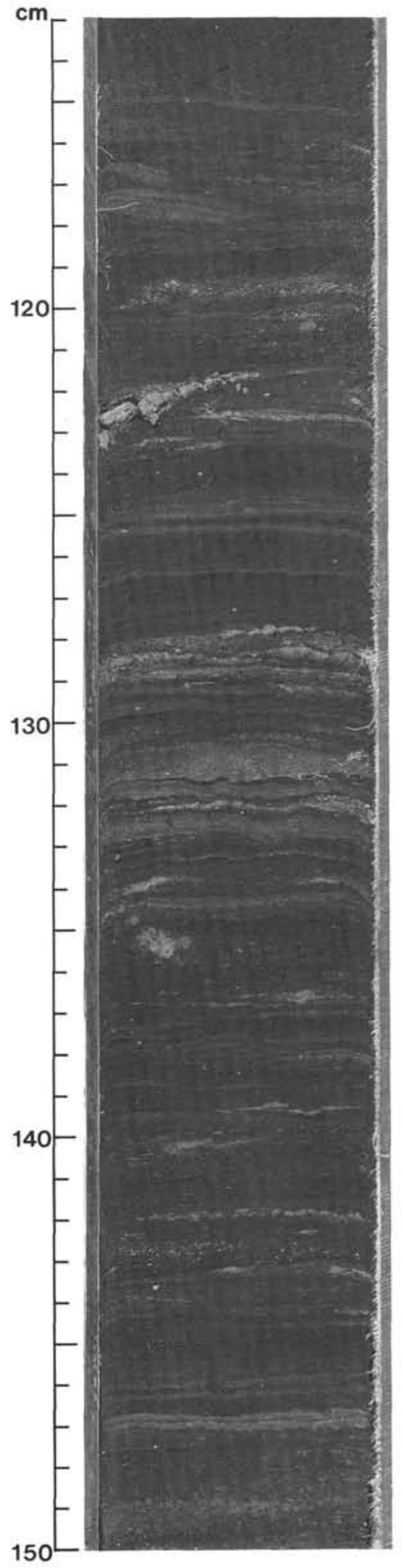

Figure 5. Laminated Quaternary diatomaceous mud with layers and small nodules of F-phosphate at the levels indicated by the letter F (112-680B-6H-6, 113-150 cm). 


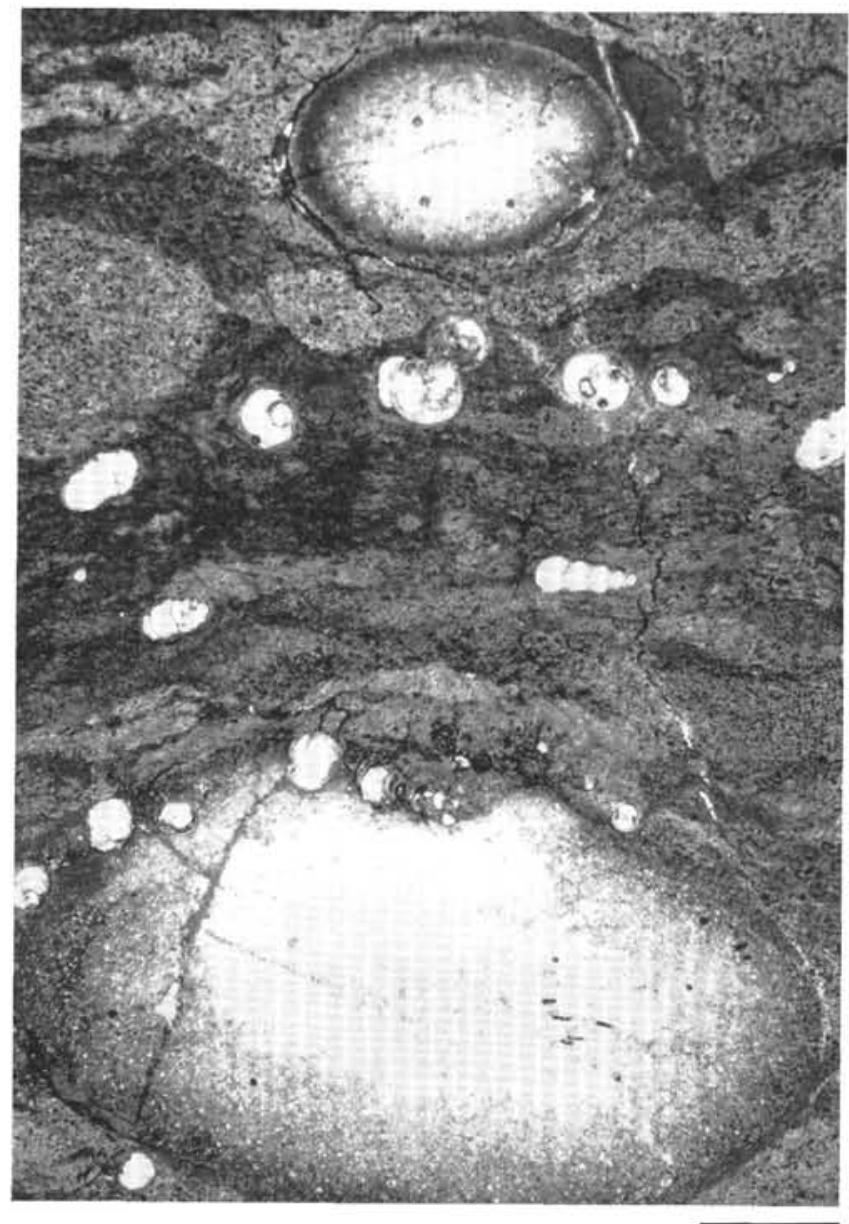

Figure 6. Photomicrograph showing two F-phosphate micronodules (top and bottom) in laminated, foraminiferal-bearing diatomaceous mud of Holocene age. The light-colored central portions of the micronodules are artifacts created by plucking of friable CFA during thin-section preparation. Note how the lower micronodule partially incorporates a few foraminiferal tests, indicating partial replacement of the host mud. These micronodules occur between about 5.0 and 5.5 mbsf, suggesting phosphatization during early diagenesis (Sample $112-679 \mathrm{~A}-10 \mathrm{H}-4,120-125 \mathrm{~cm}$; scale bar is $1 \mathrm{~mm}$ ).

they may form the matrix in gravel beds composed mainly of reworked D-nodules. These sands occur as laminae and graded layers up to $1 \mathrm{~m}$ thick (e.g., Section 112-680B-11H-1) interbedded with low-energy diatom muds (Fig. 9). As will be discussed later, P-sands in a few places (e.g., Site 684) fill elaborate burrow systems (Figs. 11 and 12).

\section{Petrography of P-Phosphates}

The major kinds of phosphatic grains in these sands are, in order of their abundance, (1) peloids, (2) coated grains, (3) fish bones, and (4) phosphatic intraclasts. Peloids (Figs. 13 through 15) are ovoid grains composed of phosmicrite, which in thin section appears largely structureless, although in a few cases, faint outlines resembling microcellular structures can be observed. Likewise, the phosmicrite rinds of coated grains are mostly structureless, with sporadic suggestions of poorly preserved cellular structures. Some coated grains have concentric layers around their nuclei, indicating incremental growth. Scanning electron microscopy observations (Figs. 16 and 17) show distinct differences in CFA crystallite morphology and packing in these layers, with the crystallites often

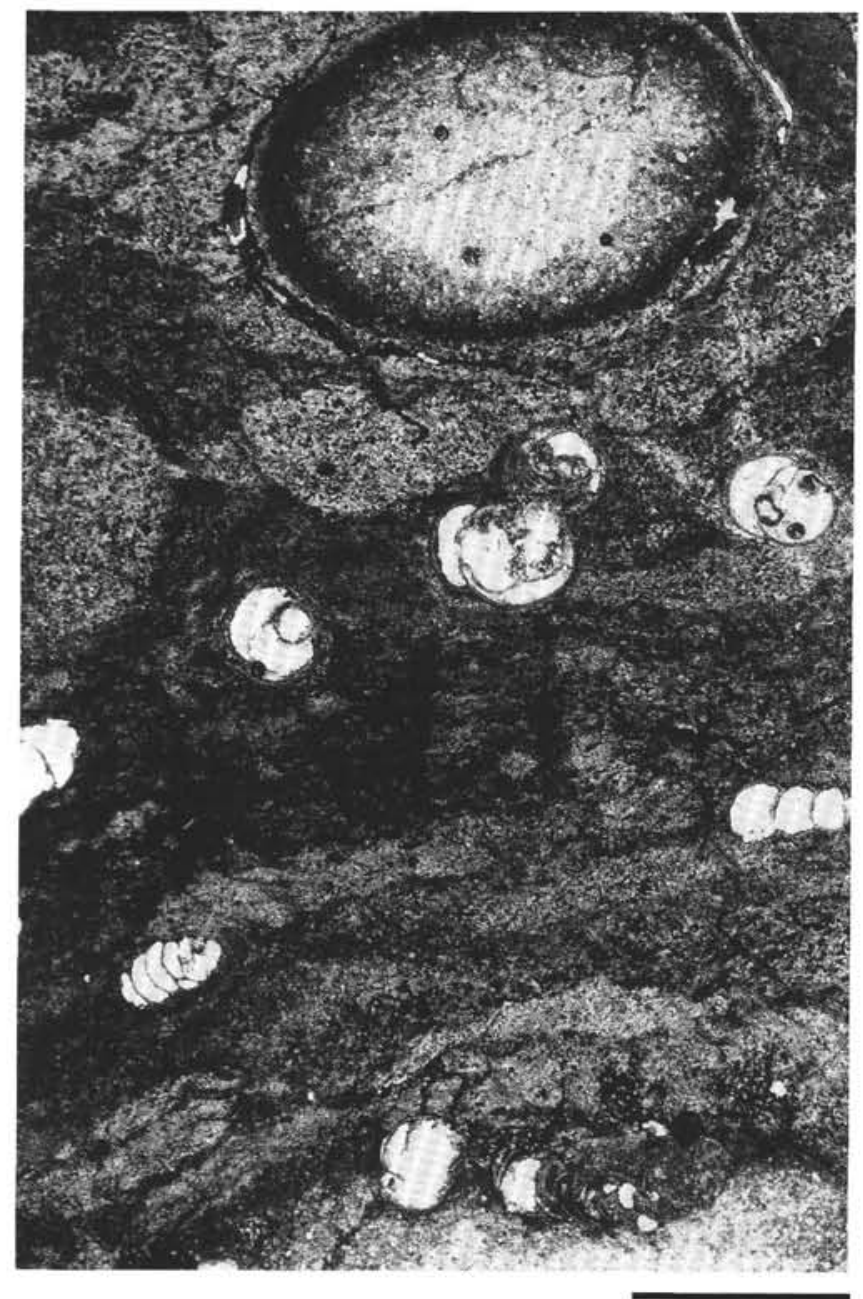

Figure 7. Photomicrograph showing detail of upper F-phosphate nodule shown in Figure 6 . Note compactional bending and distortion of light gray diatom-rich laminae in the host mud (Sample 112$679 \mathrm{~A}-10 \mathrm{H}-4,120-125 \mathrm{~cm}$, Holocene; scale bar is $1 \mathrm{~mm}$ ).

nucleated on broken diatom frustules (Fig. 17) and having shapes resembling apatites formed by microbial mediation (Lucas and Prevot, 1984, 1985). Dahanayake and Krumbein (1985) and Gerdes and Krumbein (1987) showed how coated grains, including "pseudo ooids" composed of both carbonate and phosphate, can be developed in situ during bacterial degradation of organic matter, without rolling in an agitated environment.

Coated grains have varied kinds of nuclei (Figs. 13 through 15). The most common are phosphatic peloids; somewhat less abundant are fish-bone fragments and silt- to fine sand-size siliciclastic grains. Elongated fish-bone nuclei often have thin (20-50 $\mu \mathrm{m})$ phosmicrite coatings, and phosmicrite partly replaces some fish-bone fragments (Figs. 13 and 15). Coated grains having multiple nuclei (the latter include peloids, fish bones, and silt-size siliciclastic grains) are less common than single-nucleus coated grains. These grains may be transitional to phosphatic intraclasts and may record the same kind of cementation on or near the seafloor. Phosphatic intraclasts (Fig. 13) are rounded to subrounded grains, are most abundant in the coarser grained P-phosphates, and are of several varieties. Most common are siliciclastic siltstones cemented by phosmicrite. Another variety of intraclast consists of 


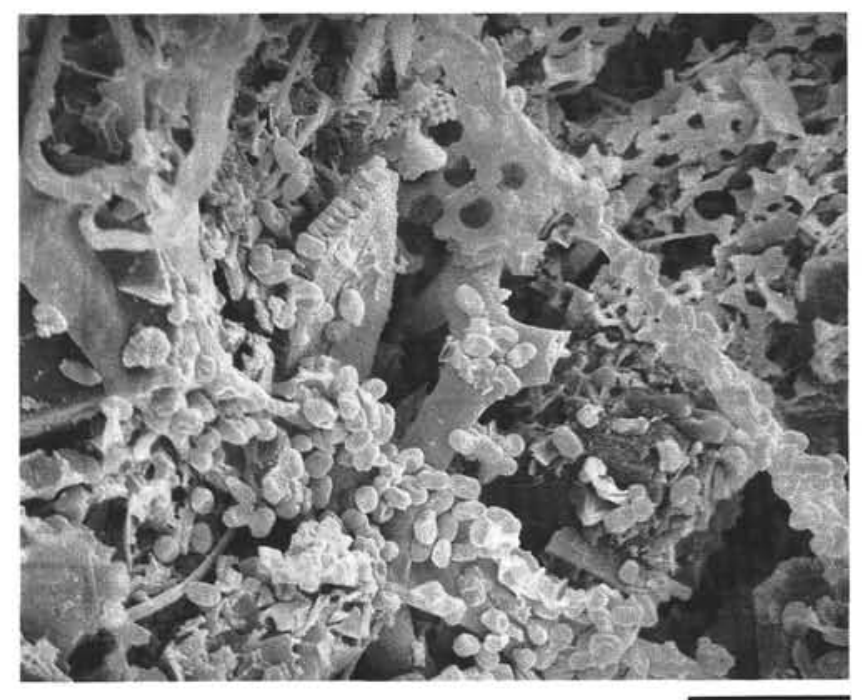

Figure 8. Scanning electron microscope photo of small globular CFA structures, of possible microbial origin, attached to fragments of diatom frustules near the edge of an F-phosphate micronodule (Sample $112-686 \mathrm{~A}-6 \mathrm{H}-4,147-150 \mathrm{~cm}$, Quaternary; scale bar is $5 \mu \mathrm{m}$ ).

phosphatic peloids cemented in a matrix of finely crystalline authigenic carbonate, probably dolomite. Other intraclasts are identical to the D-phosphates described later.

\section{Origin and Significance of P-Phosphates}

The origin of the P-phosphatic sands was probably complex and related to phosphatization processes that formed the F- and D-phosphates. Many of the peloids in the P-sands may have formed originally as F-peloids dispersed in organic-rich muds and, subsequently, became concentrated in sandy layers by winnowing and erosion due to currents, a process that also concentrated fish debris. However, other origins for phosphatic peloids, including organically induced grain diminuation (or phosmicritization) of fish bones, were described by Soudry and Nathan (1980); thus, many of the peloids may have formed by diagenesis on the seafloor, rather than after burial in muds. In addition, a much more complex history is evident from the abundance of coated grains. These grains indicate repeated episodes of CFA precipitation, perhaps bacterially mediated, directly on or just beneath the seafloor. Gerdes and Krumbein (1987) emphasized the propensity of microbial communities to colonize any hard surfaces in sediments. Thus, many or most coated phosphatic grains may be a record of such colonization, followed by phosphatization of the microbial coatings (cf. Soudry and Champetier, 1987; Dahanayake and Krumbein, 1985; Soudry, 1987).

As will be discussed later, some D-phosphates formed by cementation of P-phosphatic sands; and apparently some grains in the P-phosphates were in turn derived by erosion and reworking of lithified D-phosphates.

P-phosphatic sands are well-sorted, high-energy deposits interbedded with quiet-water, low-energy diatom muds (the dominant sediment at these sites). As such, the sands are a record of the imposition of higher-energy conditions and sediment reworking on normally quiet-water environments, possibly through large storms or storm-induced gravity flows or through more persistent currents, such as episodic, bottomhugging undercurrents or shallow-water currents acting on the bottom during periods of lowered sea level. Unfortunately, we did not observe diagnostic sedimentary structures that would allow reconstruction of the depositional processes (e.g., hum-

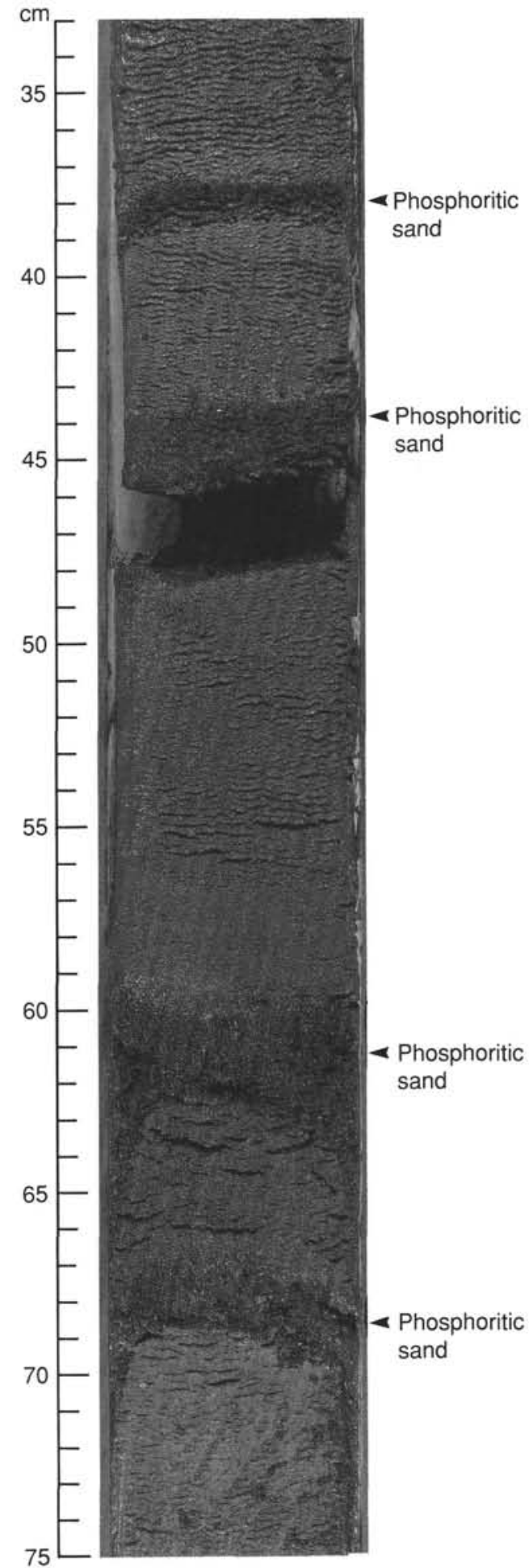

Figure 9. Core photograph showing four thin layers of P-phosphate sands interlayered with silty diatomaceous mud of Quaternary age (interval 112-681B-15X-1, 33-75 cm).

mocky cross stratification). The only structure noted was graded bedding, suggesting that the final depositional event involved a waning current.

Kim and Burnett (1988) and Baker and Burnett (1988) found that the Quaternary pellets they examined off Peru occur within poorly sorted sediment; they concluded that 

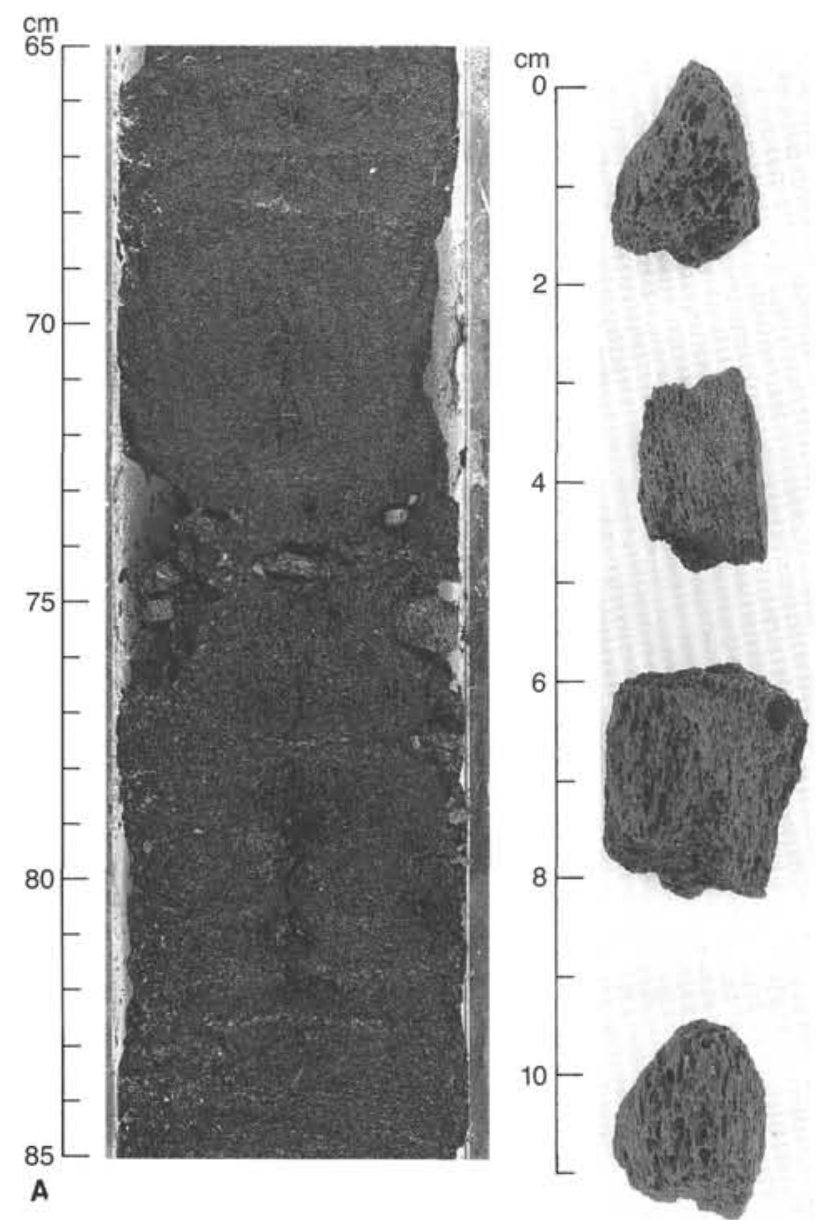

B

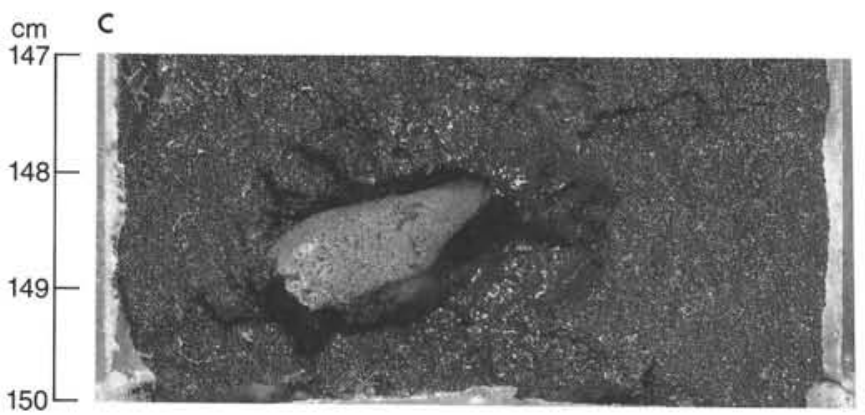

Figure 10. A. Dark P-phosphate muddy sand consisting mainly of phosphate peloids with subordinate glauconite and siliciclastic grain and scattered mammalian bone fragments (interval 112-684C-7X-1, $65-85 \mathrm{~cm}$, Pliocene). B. Close-up of bone fragments from Sample 112-684C-7X-1, 75-76 cm, Pliocene. C. Glauconitic P-phosphate sand with bone fragment (Sample 112-684C-7X-1, 147-150 cm, Pliocene).

these pellets could not have accumulated through extensive reworking. This led them to postulate that the pellets formed in situ at uniform rates, but that varying rates of detrital sediment influx produced differences in pellet concentrations. Our observations of the pellet-(peloid) rich layers sampled during Leg 112, most of which are well sorted, do not support this interpretation. We suggest that the poor sorting in some P-phosphate layers may be caused by fine sediment sizes introduced into P-phosphate layers (most of which are burrowed) by infaunal burrowing. P-phosphates are most abundant at the shallowest shelf sites $(680,681$, and 687 ; Fig. 2 and

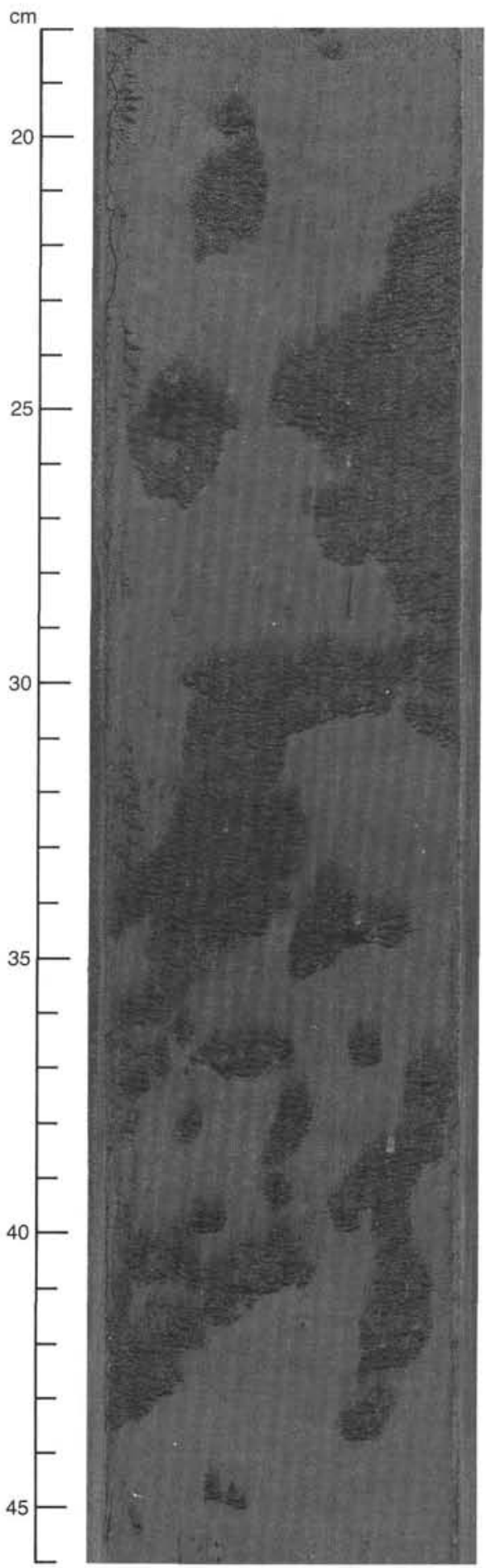

Figure 11. Large burrows filled with P-phosphate sand of probable Pliocene age occur within Miocene diatomaceous mud; the P-phosphate sands have been piped down into large Thalassinoides burrows for more than $2 \mathrm{~m}$ below an unconformable surface separating the Miocene and Pliocene at this location (cf. Figs. 5 and 12; interval $112-684 \mathrm{~A}-7 \mathrm{H}-2,18-46 \mathrm{~cm})$. 

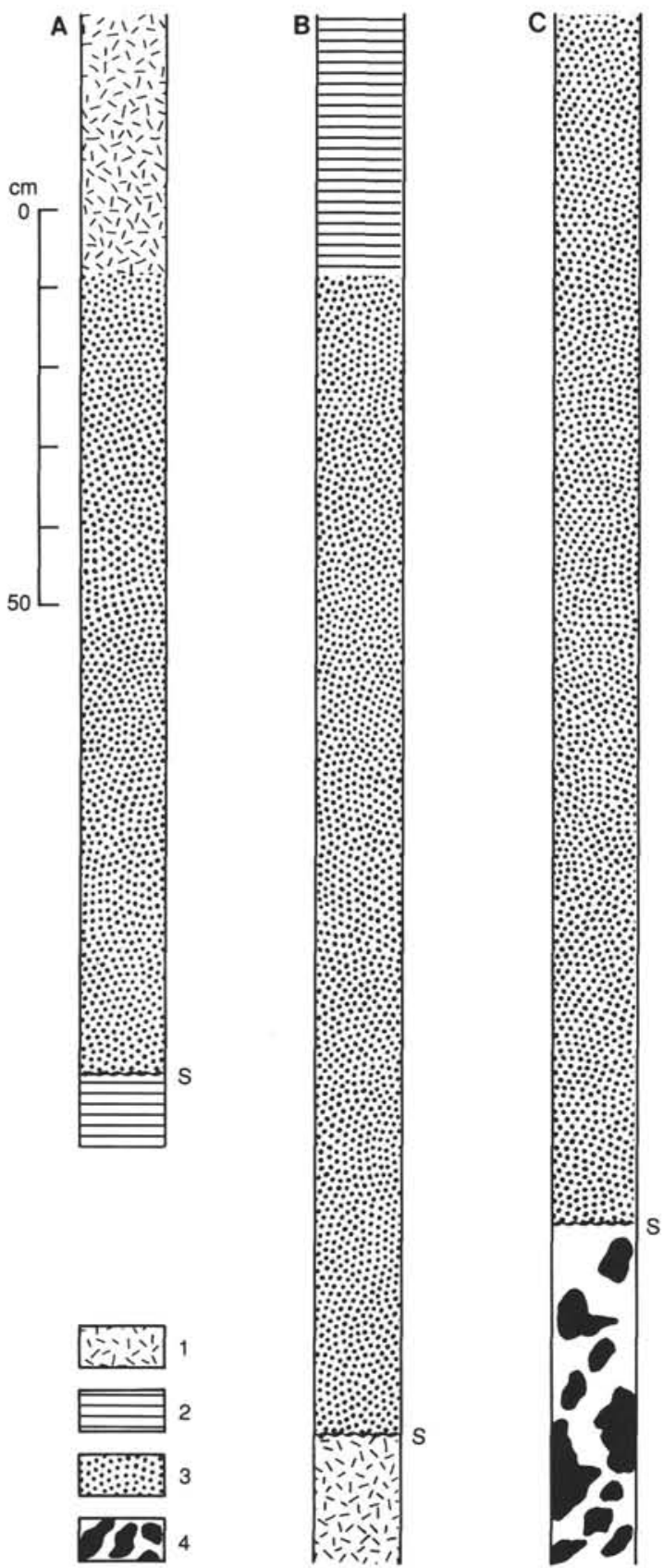

Figure 12. Selected examples of graded P-phosphatic beds associated with unconformable surfaces; traced from core photographs from Hole 684A. Symbols are $1=$ burrowed diatomaceous mud, $2=$ laminated diatomaceous mud, $3=\mathrm{P}$-phosphatic silty sand, $4=$ large Thalassinoides burrows filled with P-phosphatic sand, and $\mathrm{S}=$ scoured erosional surface. A. Graded P-phosphatic layer below burrowed diatomaceous mud and above laminated diatomaceous mud (Section 112-684A-2H-8, Quaternary). B. A thick, graded P-phosphatic sand layer lies above burrowed diatomaceous mud and below laminated diatomaceous mud; the P-phosphate consists of phosphatic peloids, foraminiferal tests, shell debris, and scattered D-phosphate nodules and phosphatic bone fragments. The scoured basal contact of this bed is an unconformity that separates Pliocene and upper Quaternary sediments (Sections 112-684A-2H-5 and 112-684A-2H-6). C. The scoured basal contact of the thick glauconite-bearing, Pphosphatic sand layer marks an unconformity that separates coarse, high-energy Pliocene sediments from the underlying low-energy Miocene diatomaceous muds. Associated with this unconformity is a network of large Thalassinoides burrows (cf. Figs. 5 and 11; Sections $112-684 \mathrm{~A}-7 \mathrm{H}-1$ and $112-684 \mathrm{~A}-7 \mathrm{H}-2)$.

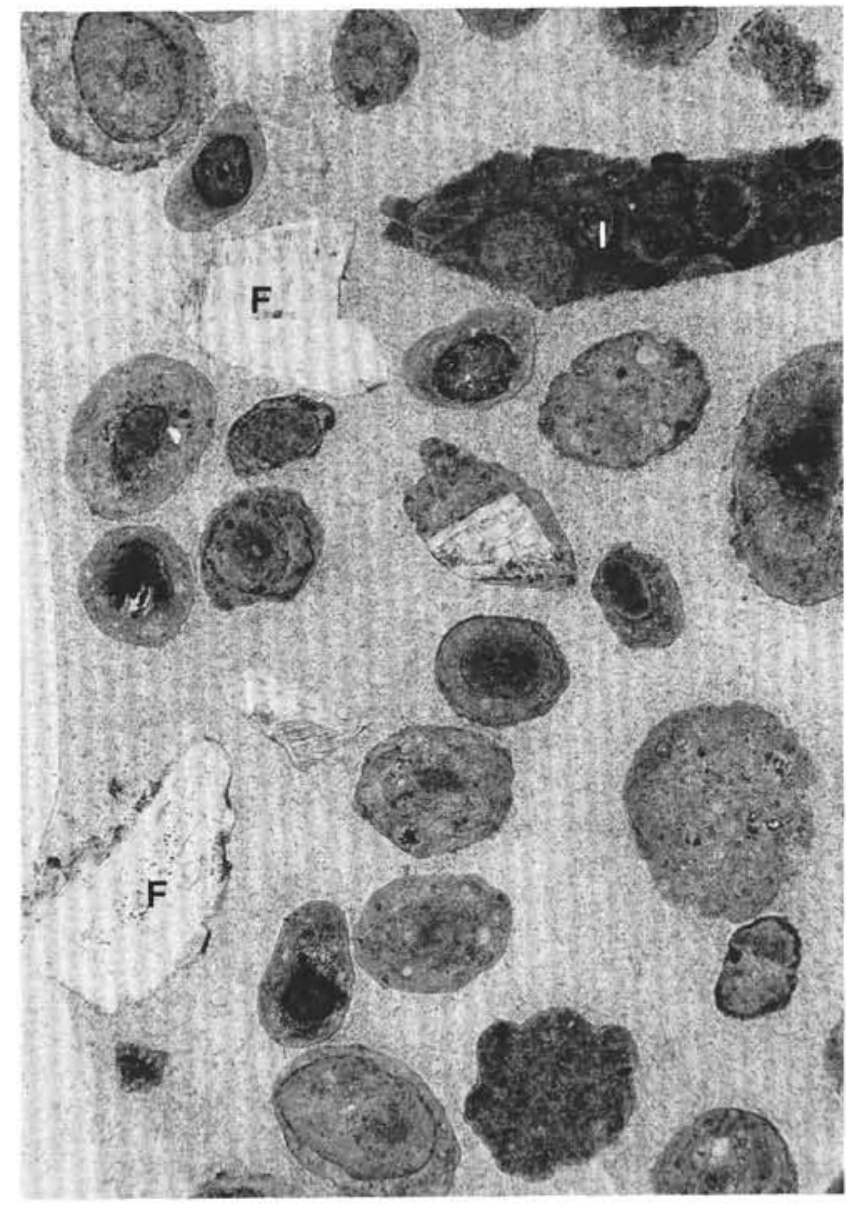

Figure 13. Photomicrograph of Pliocene P-phosphatic sand composed of coated and uncoated peloids, fish debris (F), and phosphatic intraclasts (I). Note the discontinuous and non-uniform distribution of phosphatic rims on most coated grains (Sample 112-680B-1H-1, $106-108 \mathrm{~cm}$; scale bar is $1 \mathrm{~mm}$ ).

Table 1), which are the localities most likely affected by storms or lowstands in sea level. Among the deeper water sites, P-phosphates are common only at Site 684 in Pliocene sediments that contain evidence for shallower water deposition, compared with today's depth.

Thus, P-phosphates mark interruptions in the normal quietwater upwelling sedimentation along the Peru margin (cf. Fig. 12). In this respect they are akin to D-phosphates (see below), but because, in contrast to D-phosphates, they are uncemented, we surmise that they indicate shorter interruptions in the deposition of diatom muds.

\section{D-Phosphates}

\section{General Characteristics}

D-phosphates are well-cemented, typically dark-colored phosphatic rocks that occur in shelf and upper-slope sediments as nodules (Fig. 18), thin hardgrounds (Figs. 19 through 21), gravel beds (Figs. 22 through 24), and as layers of nodules (Fig. 25). These nodules are irregularly shaped and range from about 2 to $10 \mathrm{~cm}$ wide. Some nodules show small borings (Fig. 18), and their consistency varies from slightly porous to very dense and compact; the latter varieties nearly always have a dark brown to black external rind. Nodules are present in thin beds and, along with P-phos- 


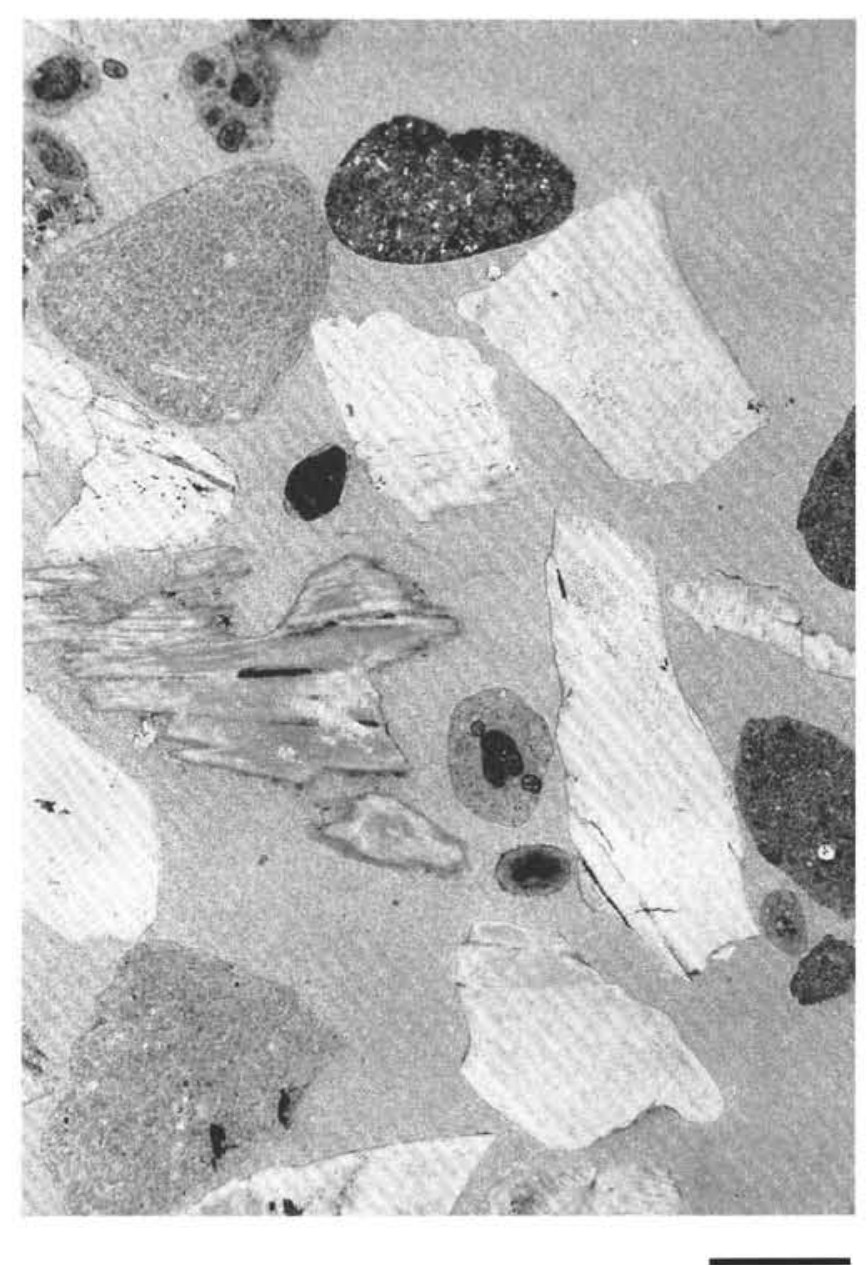

Figure 14. Photomicrograph of coarse grained P-phosphatic sand of Pliocene age. Note abundance of coarse fish debris and rounded, uncoated phosphatic peloids; Sample 112-680B-11H-1, 123-125 cm; scale bar is $1 \mathrm{~mm}$.

phatic sands, as burrow-fillings (Fig. 22). These nodules also occur in gravel layers up to $1.5 \mathrm{~m}$ thick, where they tend to be concentrated in the basal coarse portion, along with bone and shell fragments in some localities (Fig. 24). At several sites these gravels lie above scoured surfaces, on top of dolomitized beds (Figs. 22-24), which suggests that erosion preceding deposition of the gravels cut down through unlithified mud until it was impeded by an early-formed dolomite layer.

Hardgrounds were the least abundant form of D-phosphate encountered during Leg 112; however, this may be in part an artifact of coring, which tends to break thinly cemented layers into a rubble of fragments that resemble nodular layers. The best examples are at Site 686, where several phosphatic hardgrounds up to $10 \mathrm{~cm}$ thick are interbedded with diatom muds (Figs. 19 through 22). Distinctive at this site are hardgrounds having planar tops and bulbous lower surfaces (Fig. 21 ), suggesting they grew downward from the sediment-water interface in the manner demonstrated by Burnett et al. (1982) for nodules recovered in surface sediments on the Peru shelf. These hardgrounds are composed of cemented nodules and thus record multiple episodes of phosphogenesis, as detailed below. That D-phosphates formed near the seafloor is suggested by the presence of organic borings (Figs. 18 and 20) and

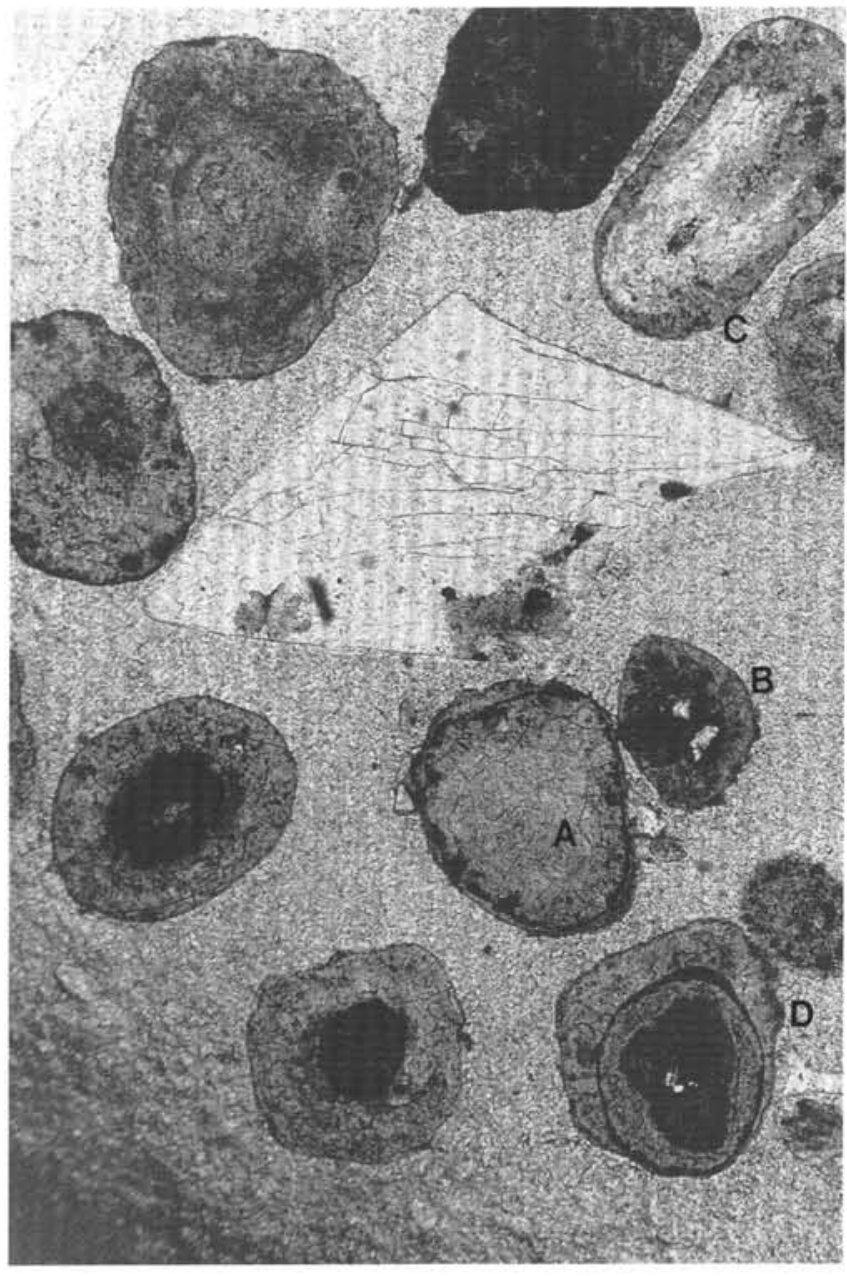

Figure 15. Photomicrograph of Pliocene P-phosphatic sand showing a variety of coated peloids as well as fish bone (light grain at center) and a largely uncoated peloid (A). Note the peloid with two silt-size siliciclastic nuclei (B), thin phosmicrite coating that partly replaces its fish bone nucleus (C), and the partial phosphatic rim on a nucleus of a concentrically laminated peloid (D). Note also, in the upper left corner, the two coated peloids in which the coatings are becoming indistinct, perhaps illustrating a stage in the development of structureless peloids like that represented by grain (A); Sample 112-680B$11 \mathrm{H}-1,106-108 \mathrm{~cm}$; scale bar is $1 \mathrm{~mm}$.

by their occurrence at sub-bottom depths as shallow as $0.65 \mathrm{~m}$ (Sample 112-687B-1H-1, $65 \mathrm{~cm}$ ).

\section{Petrography of D-Phosphates}

Thin-section studies show that D-phosphates formed by the cementation, and in some cases partial replacement, by CFA of five types of primary sediment, as follows:

1. Sands composed almost entirely of foraminiferal tests.

2. Sands composed almost entirely of phosphatic peloids and coated grains (Fig. 26).

3. Sands composed dominantly of silt- to fine sand-size siliciclastic grains (Figs. 27C and 28).

4. Sands consisting of a mixture of siliciclastic grains, phosphatic peloids, and phosphatic coated grains, in some instances with an admixture of fish bones and foraminiferal tests (Figs. 27B, 27C, and 27D). This is the most common 


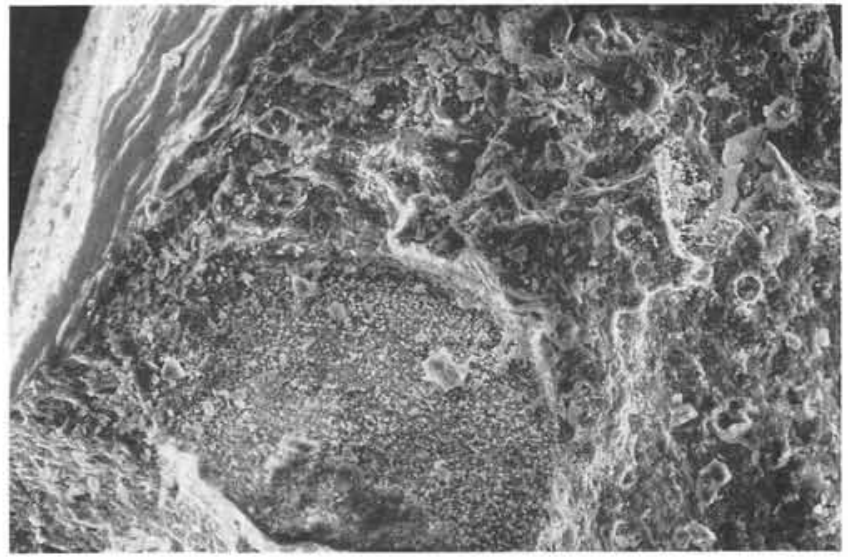

A

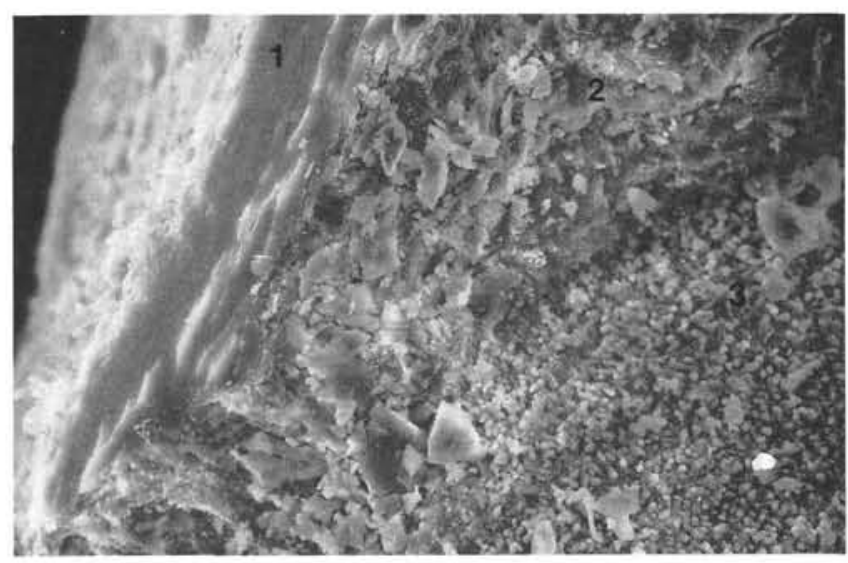

B

Figure 16. Low-magnification SEM photographs of a coated Pphosphate peloid showing outer rims (Sample 112-680B-1H-1, 123$125 \mathrm{~cm}$, Pliocene,; scale bars equal $100 \mu \mathrm{m})$. A. The broken corner of this peloid reveals the three outermost layers. B. Detail of the three layers in the peloid: (1) the outer layer is a smooth, dense rind, perhaps a phosphatized microbial coating, (2) below this is a porous and loosely packed layer of fragmented diatom frustules cemented by bundles of fibrous CFA (cf. Figs. 17A and 17B), (3) the inner layer is a somewhat more densely packed mass of fragmented diatom frustules more compactly cemented by stubby CFA crystals (cf. Fig. 17C).

variety of D-phosphate and may also contain phosphatic intraclasts.

5. Diatom muds (Figs. 27A and 27B). These D-phosphates are generally relatively homogeneous and contain only sparse included diatom frustules, foraminiferal tests, and detrital siliciclastic grains.

D-phosphate nodules and hardgrounds are compound entities having complex sedimentological and diagenetic histories. Some phosphatic intraclasts, for example, contain intraclasts of earlier formed and eroded phosphatic layers. Most D-phosphates contain more than one of the host sediment varieties noted previously, and each nodule and hardground contains its own internal "microstratigraphy." When present in nodules, phosphatized diatom mud (type 5) is typically the oldest generation of phosphate, forming, for example, the cores of D-nodules (Fig. 27B). Such clasts of phosphatized diatom mud were apparently F-phosphate micronodules that were eroded and redeposited from their diatom-mud host sediment (in a few cases, this kind of phosphatization may have nucleated around fish bones [Fig. 27A], and fish-bone nuclei were also noted in D-nodules composed of type 4

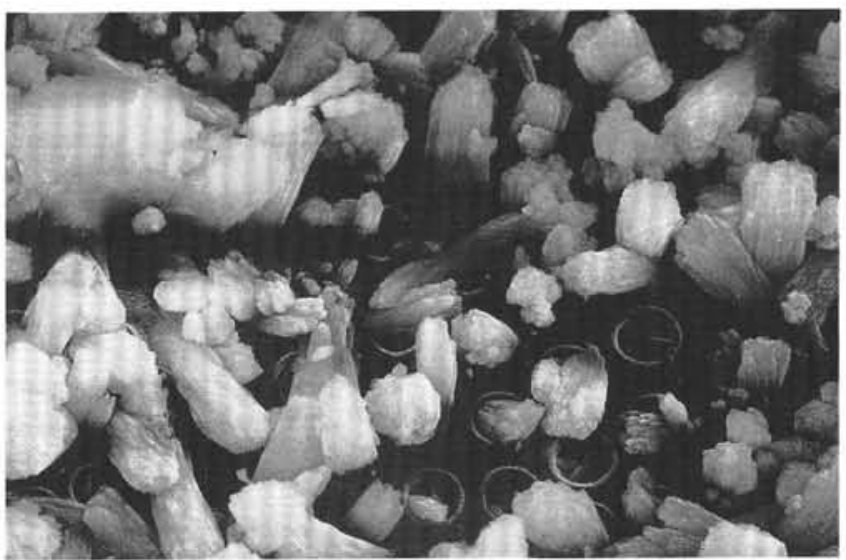

A

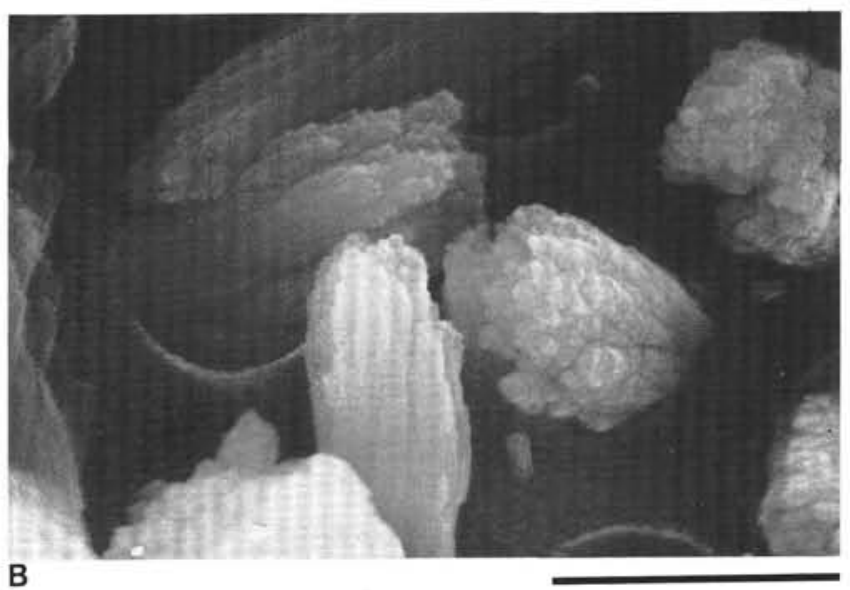

B

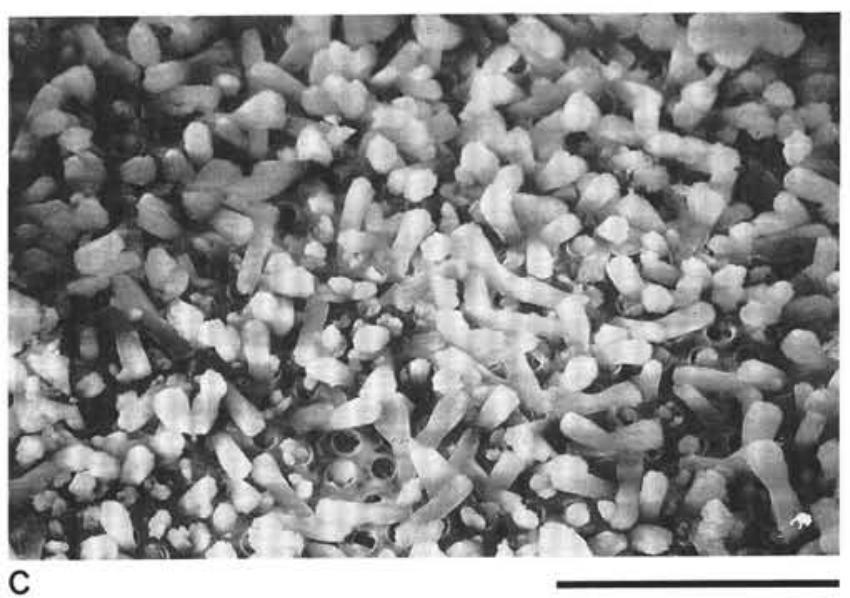

Figure 17. High-magnification SEM photographs of cements in the coated peloid illustrated in Figure 16 (Sample 112-680B-11H-1, 123 $125 \mathrm{~cm}$, Pliocene). A. Bundles of fibrous CFA cement crystals nucleated on a diatom frustule (cf. layer 2 in Fig. 16B); scale bar is 10 $\mu \mathrm{m}$. B. Enlarged view of a portion of above, showing growth of fibrous CFA bundles in pores and on the surface of a diatom frustule; scale bar is $2 \mu \mathrm{m}$. C. Stubby equigranular crystals of CFA forming the cement in layer 3 (cf. Fig. 16B); scale bar is $20 \mu \mathrm{m}$.

sands). Not all type 5 D-nodules, however, can be explained by simple reworking of F-micronodules because the latter are very small (usually less than 2 to $3 \mathrm{~cm}$ wide), whereas the former are up to $10 \mathrm{~cm}$ wide. Furthermore, the type 5 portiors of many D-nodules show accretionary rims and microlaminated crusts of phosmicrite (Fig. 28), indicating continued growth after they were exhumed and reworked. 


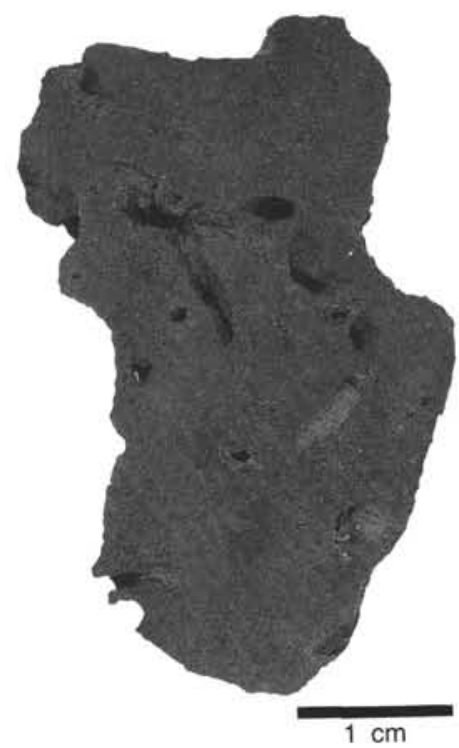

Figure 18. Miocene D-phosphate nodule containing unfilled borings, possibly made by bivalves (Sample 112-684A-11X-CC, $0-4 \mathrm{~cm}$ ).

Figures 27 and 28 illustrate some of the variety of textures and microstratigraphies present in D-phosphates. Different generations of phosphatic sediment in individual nodules typically have, in addition to different types of sediment, different types of phosphatic cement. Following the terminology of Glenn and Arthur (1988a), we recognized two main varieties of cements. Fringing cements (Figs. 26A and 26B) are microcrystalline, anisotropic CFA cements that form thin $(2-10 \mu \mathrm{m})$, even rims around grains, usually phosphatic peloids and coated grains. These cements are the result of CFA precipitation in large pores of well-sorted phosphatic sands, most often type 2 sands. Individual crystallites tend to have a preferred elongation perpendicular to grain surfaces and are usually length-fast, but observations with the scanning electron microscope (Figs. 29 and 30) reveal a variety of complex fabrics within fringing cements. Most common are stubby euhedral crystallites, often twinned, that line voids (Figs. 29A and 29C). Next in abundance are globular and ellipsoidal structures (Figs. 29B, 29D, 30A, and 30B) that resemble phosphatized microbial cells described previously by a number of authors (e.g., Soudry and Lewy, 1988). Typically, the globular bodies formed first on the walls of microcavites and were succeeded by formation of the ellipsoidal structures (Figs. $30 \mathrm{~A}$ and 30B) or CFA crystallites (Fig. 31D). Two other kinds of distinctive fabrics are less common. One kind consists of thin coatings of platy hexagonal crystallites that form thin rims on grains (Fig. 30C); where present, they constitute the earliest part of fringing cements and are overlain by later fabrics (Fig. 30D). Another kind consists of rosettes of acicular CFA crystallites (Fig. 29B); Soudry and Lewy (1988) illustrated a similar fabric, which they interpreted as the interior fillings of phosphatized microbial globules. This variety of fabrics suggests fluctuations in chemical and biochemical conditions during the precipitation of CFA fringing cements.

More common than fringing cements are interstitial $C F A$ cements. As noted by Glenn and Arthur (1988a), these cements range from cryptocrystalline or phosmicrite matrices, which are pseudo-isotropic, inclusion-rich, and usually dark in thin sections, to clearer, translucent, and more birefringent varieties transitional with fringing cements (Figs. 26C, 26D, 27B, and 27C). Interstitial cements are typical in poorly sorted sands. At high magnifications (Fig. 31) the main fabric observed is a compact mass of anhedral to subhedral, submicrometer-size

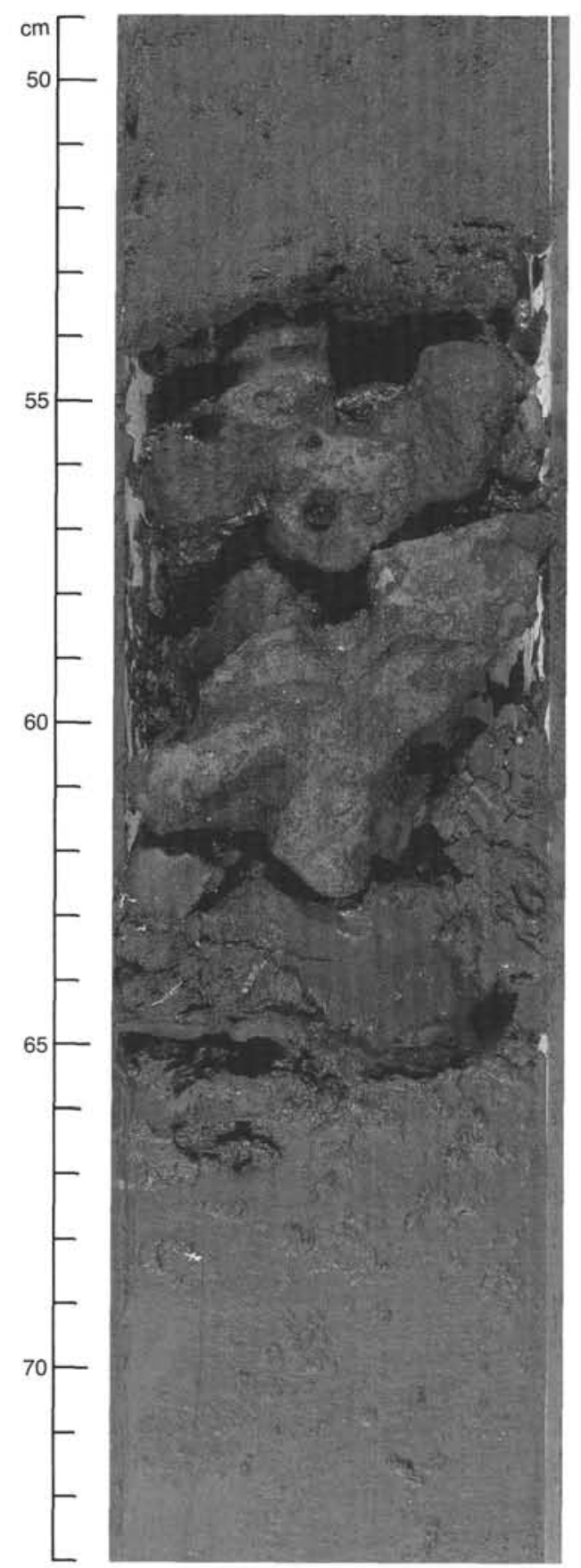

Figure 19. Quaternary D-phosphate hardground. The mottled appearance of the phosphate results from different generations of phosphatization, each of which produced somewhat different colors and textures. See Figure 20 for a more detailed view of this surface (interval $112-686 \mathrm{~A}-2 \mathrm{H}-2,49-73 \mathrm{~cm}$ ).

CFA crystallites, which contrast markedly with the generally coarser fringing cements that may line voids in the same rock (Fig. 31B).

In many cases, there is a gradation from fringing cements at the edges of grains and voids to interstitial cements in intergranular and intervoid areas (Figs. 30A and 30B), indicating that the differences in cement fabric may have been controlled by the rate and extent of CFA precipitation. Older (e.g. pre-Quaternary) D-phosphates tend to be dominated by dark interstitial cements. Furthermore, even within individual nod- 


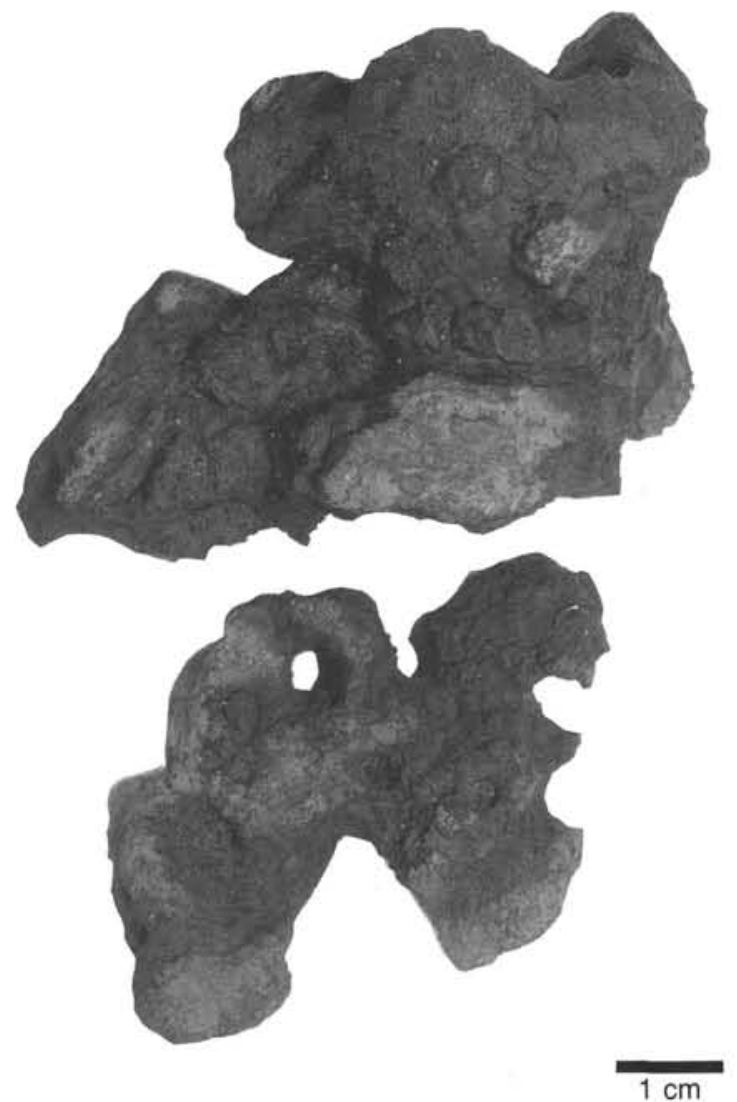

Figure 20. Close-up view of slabs from D-phosphate hardground seen in Figure 19. The slab at top has light-colored phosphate nodules cemented by a later generation of dark-colored phosphate. The slab at bottom has a small hole made by a boring organism (interval 112$686 \mathrm{~A}-2 \mathrm{H}, 48-59 \mathrm{~cm}$, quaternary).

ules, the older sediment generations always have interstitial cements, while fringing cements occur only in the younger generations (e.g., Fig. 27B). These observations suggest that fringing cements are formed first but were succeeded and, in some cases, replaced by interstitial cements through time. Glenn and Arthur (1988b) referred to this as "progressive phosphatization," a process analogous to the "convergent diagenesis" of Soudry and Nathan (1980).

Separating different sediment generations in many nodules are thin microlaminated crusts, usually inclusion-free and pseudo-isotropic (Fig. 28). Typically, these crusts form the boundaries between distinctly different types of sediment. They are most conspicuous where they line the edges of borings (Figs. $28 \mathrm{C}$ and 28D), showing clearly that they formed on lithified surfaces. Although we are uncertain about the origin of these crusts, their morphology and internal structure leads us to speculate that they were microbial mats that colonized lithified surfaces (cf. Gerdes and Krumbein, 1987) and were subsequently phosphatized. In some nodules, these crusts occur repeatedly (Fig. 28B), suggesting multiple and perhaps rapid episodes of phosphatic cementation on the seafloor, followed by mat growth and phosphatization, then renewed sedimentation and phosphatic cementation, with multiple repetitions of this cycle.

\section{Origin and Significance of D-Phosphates}

D-phosphates occur as layers within thick sequences of diatom muds, but all D-phosphates contain sand-size and coarser sediment that contrasts markedly with the fine-grained muds. They formed, therefore, during times of higher-than-normal

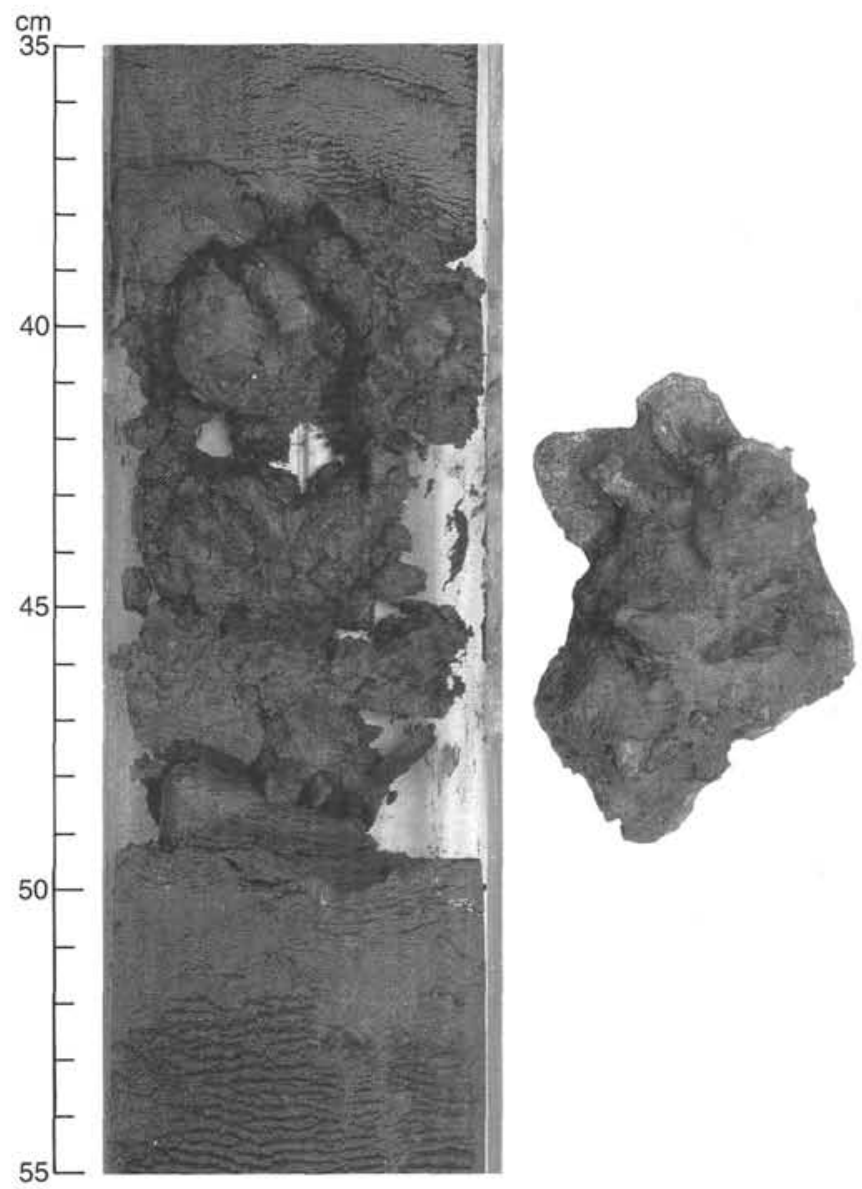

Figure 21. Quaternary D-phosphate hardground. The hardground was taken out of the core and turned upside down so that we are viewing its bulbous lower surface; the top surface is almost planar (interval $112-686 \mathrm{~A}-8 \mathrm{H}-1,35-55 \mathrm{~cm})$.

energy levels, when coarser sediment could be transported and reworked within environments where low-energy conditions normally prevailed. The variety of sediment types in individual nodules and hardgrounds indicates that coarse sediment was derived from several sources and that multiple depositional events occurred during their formation. For example, substantial amounts of erosion and redeposition of phosphatically cemented sediment occurred. Abundant biogenic borings further suggest that, interspersed with the cycles of sedimentation, cementation and erosion, periods of nonsedimentation allowed infauna to colonize lithified and exposed surfaces. D-phosphates thus mark hiatuses and indicate interruptions in quiet water deposition beneath the Peru margin upwelling system, interruptions brought about by high energy events, such as increased countercurrent velocities on the seafloor or those caused by decreases in sea level. D-phosphates are present at all shelf and upper-slope sites and are most common in sediments of Quaternary age, although they also occur in the Pliocene and Miocene (Table 1). Similar phosphates were repeatedly recovered in dredge hauls and box cores from the Peru margin (e.g., Burnett, 1977; Glenn and Arthur, 1988a).

\section{PHOSPHOGENESIS, SEDIMENTATION RATES, AND ENERGY LEVELS}

Recent pore-water studies in areas of Quaternary phosphogenesis indicate the most likely supplies of phosphorus for CFA precipitation stem either from ferrous redox cycle phosphate pumping (Froelich et al., 1988; Heggie et al., in press) or 


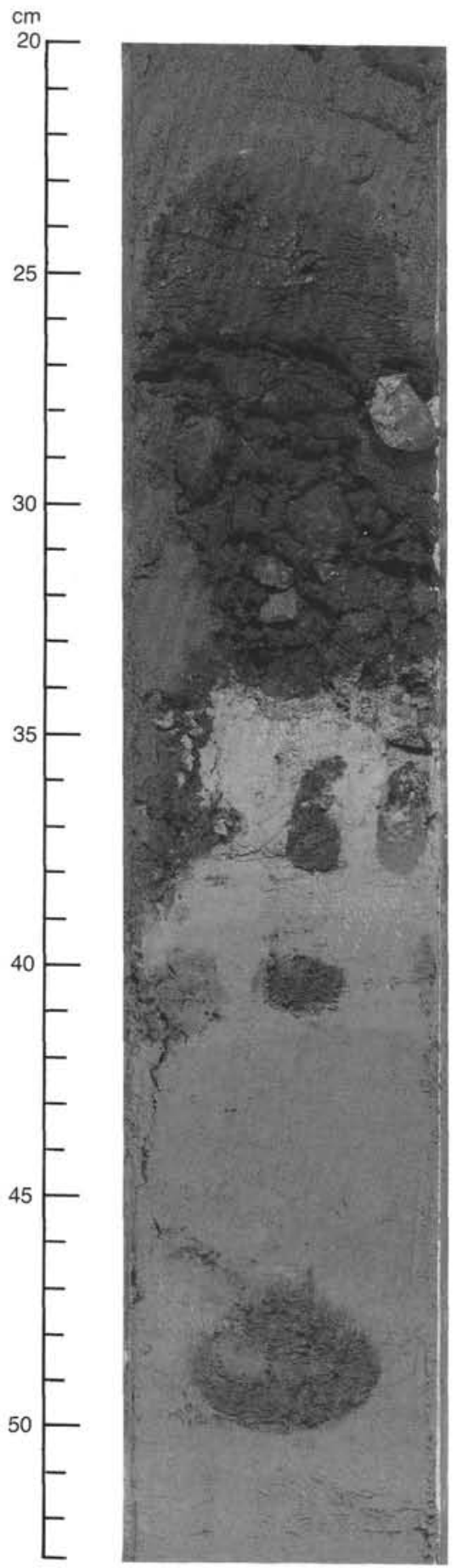

Figure 22. D-phosphate nodules at erosional contact separating light gray green (bottom of photo) and dark P-phosphatic sand (top). The transition zone between these two lithologies consists of dark brown diatomaceous mud containing dark D-phosphate nodules; some of this sediment is piped downward into large burrows. The light-colored interval between 34 and $39 \mathrm{~cm}$ consists of slightly lithified dolomite (interval 112-687A-5H-1, 20-53 cm, Quaternary).

from molecular diffusion of dissolved phosphorus from seawater (Schuffert et al., 1987), sources possibly abetted by dissolution of fish debris (Suess, 1981) and growth of microbial mats (Reimers et al., in press). All of these processes are favored by slow sedimentation or nonsedimentation. Reduced or intermittently interrupted sedimentation, accompanied by

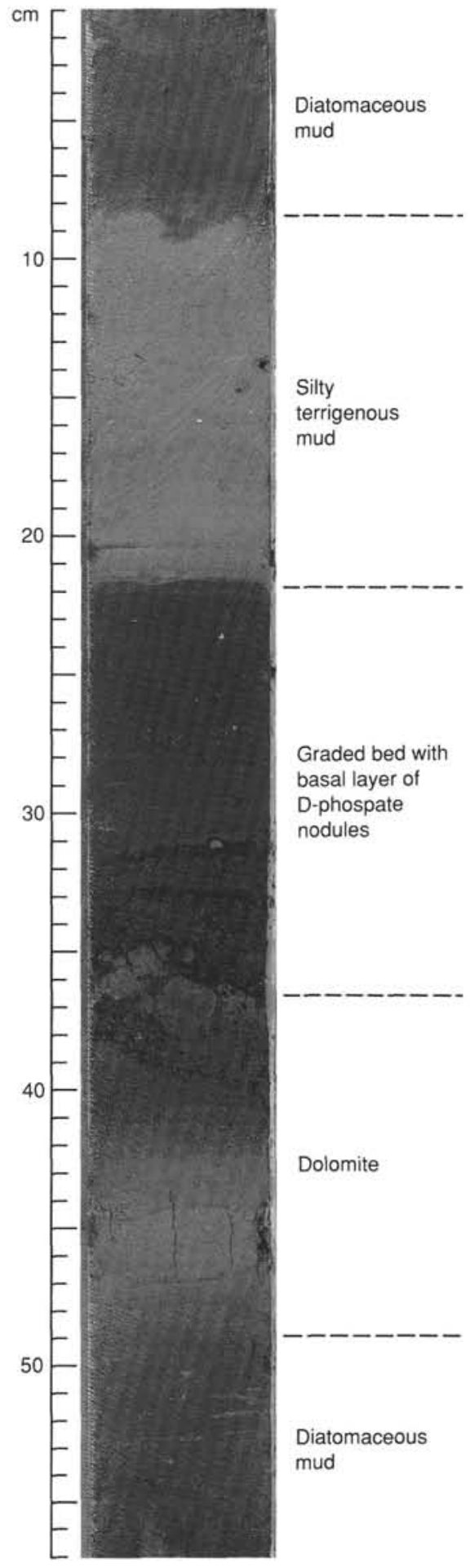

Figure 23. D-phosphate nodules occur in the basal part of a graded sandy bed that overlies a lithified dolomite layer; the contact between the two lithologies is a scoured erosional contact (interval 112$681 \mathrm{~B}-10 \mathrm{H}-2,1-57 \mathrm{~cm}$, Quaternary).

erosion, reworking, reburial, etc., was a factor in the formation of P- and D-phosphates recovered during Leg 112, and slow sedimentation can be implied for F-phosphates. In land stratigraphic sequences, rocks analogous to these three types of phosphates have been shown, through various kinds of evidence, to occur in condensed sections or at hiatuses (e.g., 


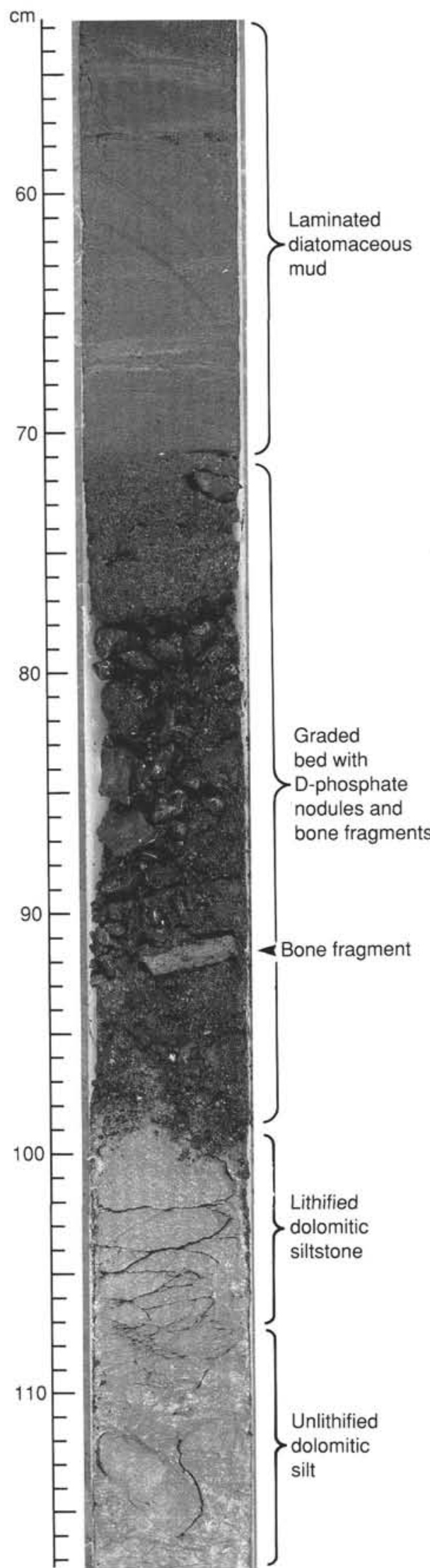

Figure 24. Pliocene conglomerate containing D-phosphate nodules and bone fragments lying above a dolomitically cemented siltstone bed along a scoured erosional surface $(112-680 \mathrm{~B}-7 \mathrm{H}-3,53-117 \mathrm{~cm})$.

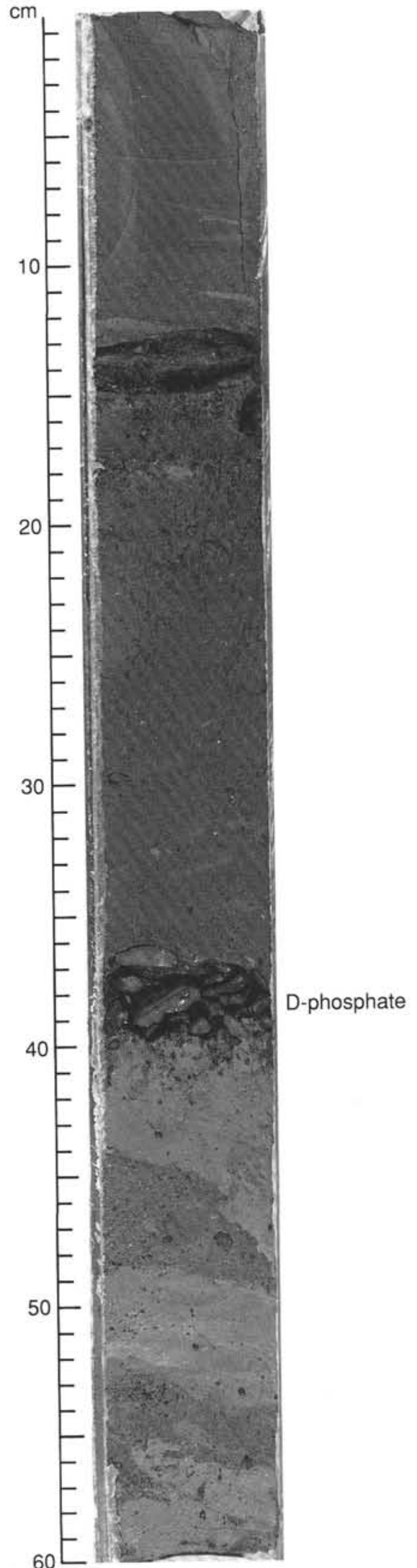

Figure 25. Thin gravel layer consisting mainly of D-phosphate nodules. The gravel lies below diatomaceous mud and silt and erosionally above a light-colored friable siltstone that is cemented by dolomite (112-680B-8H-7, 1-60 cm, Pliocene). 

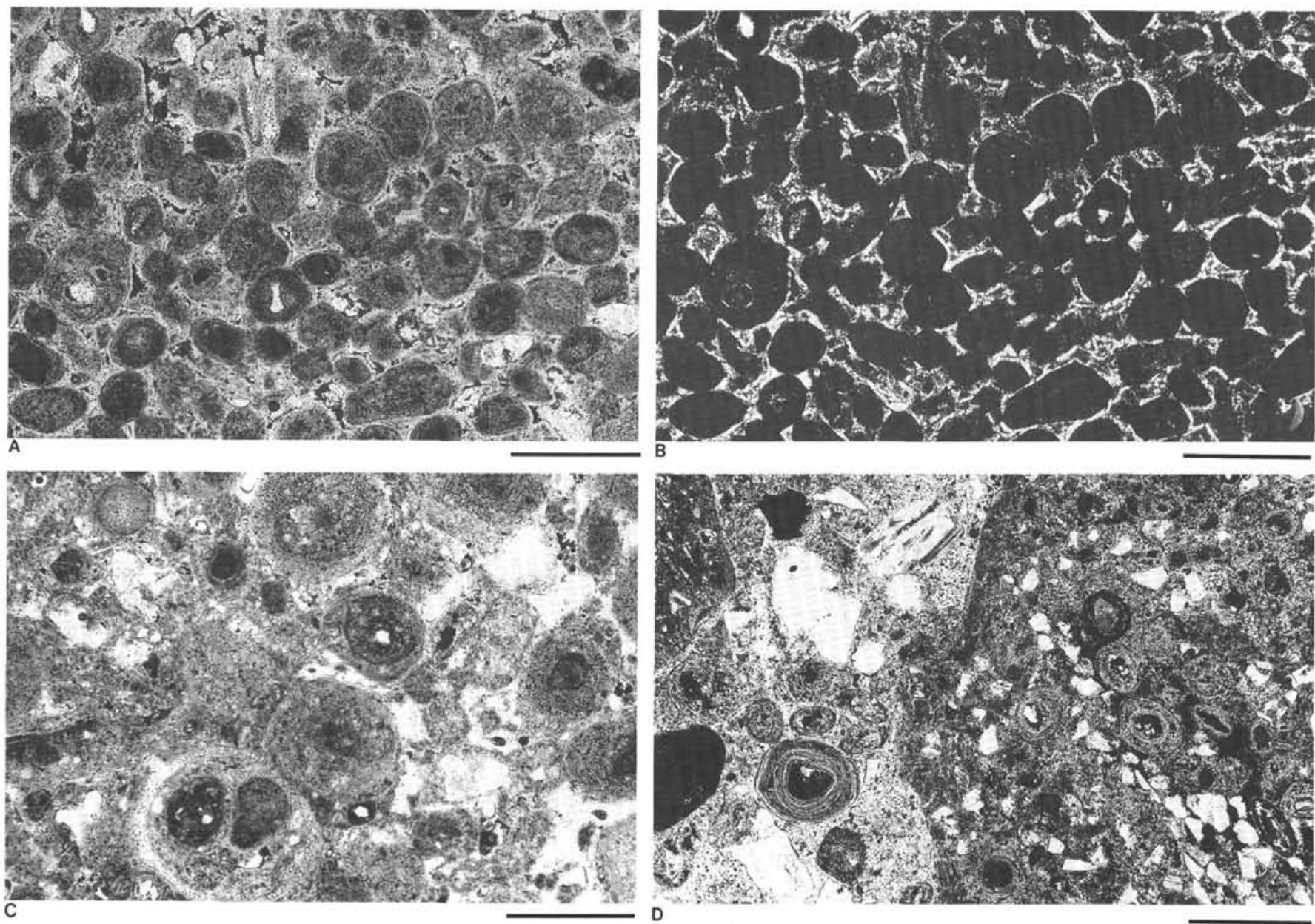

Figure 26. Photomicrographs of D-phosphate nodules in conglomerates. Scale bars equal $0.5 \mathrm{~mm}$. A. Well sorted phosphatic sandstone with fringing CFA cement. Grains include structureless peloids and coated grains having varying types and numbers of nuclei (Sample 112-679B-6 H-1, 62-63 cm, Quaternary, plane light). B. Same as A., crossed nicols; note anisotropic fringing cement of oriented CFA crystals; details of this cement are illustrated in Figures 29 and 80 . C. Cemented (interstitial CFA cement) phosphatic sand containing structureless peloids and coated grains having a variety of nuclei, including a phosphatized foraminiferal test in lower central part of the photograph; note also the scattering of silt- to fine sand-size siliciclastic grains, as nuclei and as interpeloid grains (Sample 112-680B-11H-1, 102-104 cm, Pliocene, plans light). D. Two generations of cemented P-phosphatic sandstones in a D-phosphate nodule. The older generation on the right has a dark interstitial CFA cement, the younger on the left, a translucent fringing CFA cement. Note the presence, in both generations, of coated grains with evenly laminated rims around dark peloids (Sample 112-680A-7H-1, 63-66 cm, Pliocene, plane light).

Garrison et al., 1987). Much recent research on both ancient and modern phosphorites has suggested microbial involvement in CFA precipitation (e.g., O'Brien et al., 1981; Soudry and Champetier, 1983; Krajewski, 1984; Dahanayake and Krumbein, 1985; Soudry, 1987; Soudry and Lewy, 1988). These findings were reinforced by the laboratory experiments of Lucas and Prevot (1984, 1985), who found that apatite synthesis in seawater was possible only when bacterial activity was involved, an observation they attributed to the release of phosphorus from RNA molecules during bacterial degradation. Our own studies of CFA cements in Peru margin phosphates tend to support the notion of microbial involvement (cf. Figs. 8, 29, 30, and 31), but our data do not allow us to decipher whether this involvement was active or passive.

Sedimentation rates and energy levels are important variables that control the extent of phosphogenesis, as well as the type of phosphate that forms (Fig. 32). Slow sedimentation or nonsedimentation promotes the effectiveness of redox pumping and phosphorus diffusion; this also intensifies microbial activity in the sediment at and just beneath the seafloor (including microbial mat growth). Energy levels determine the amount of winnowing and reworking as well as how long grains remain exposed on the seafloor. In this context, F-phosphates may be viewed as products of embryonic phosphatization in diatom muds during brief pauses in sedimentation within a low-energy environment. Once buried beneath the chemically reactive zone near the seafloor, this kind of phosphatization ceased. At higher energy levels, winnowing retarded sedimentation of diatom muds and led to sand deposition. Microbial coatings on sand-size grains became the loci of CFA precipitation (actively or passively mediated by microbial metabolism), leading to the genesis of P-phosphatic sands. The association of large burrows with some of these sands (Figs.11 and 12) indicates pronounced changes in the depositional environment, perhaps connected with lowering of sea level and seaward retreat of the oxygen-minimum zone.

D-phosphates may be viewed as an end-member in this spectrum. Interruptions in sedimentation were sufficiently prolonged to allow extensive CFA cementation on or directly beneath the seafloor. Energy levels were high enough to cause sediment bypassing and, at times, to permit erosion and 

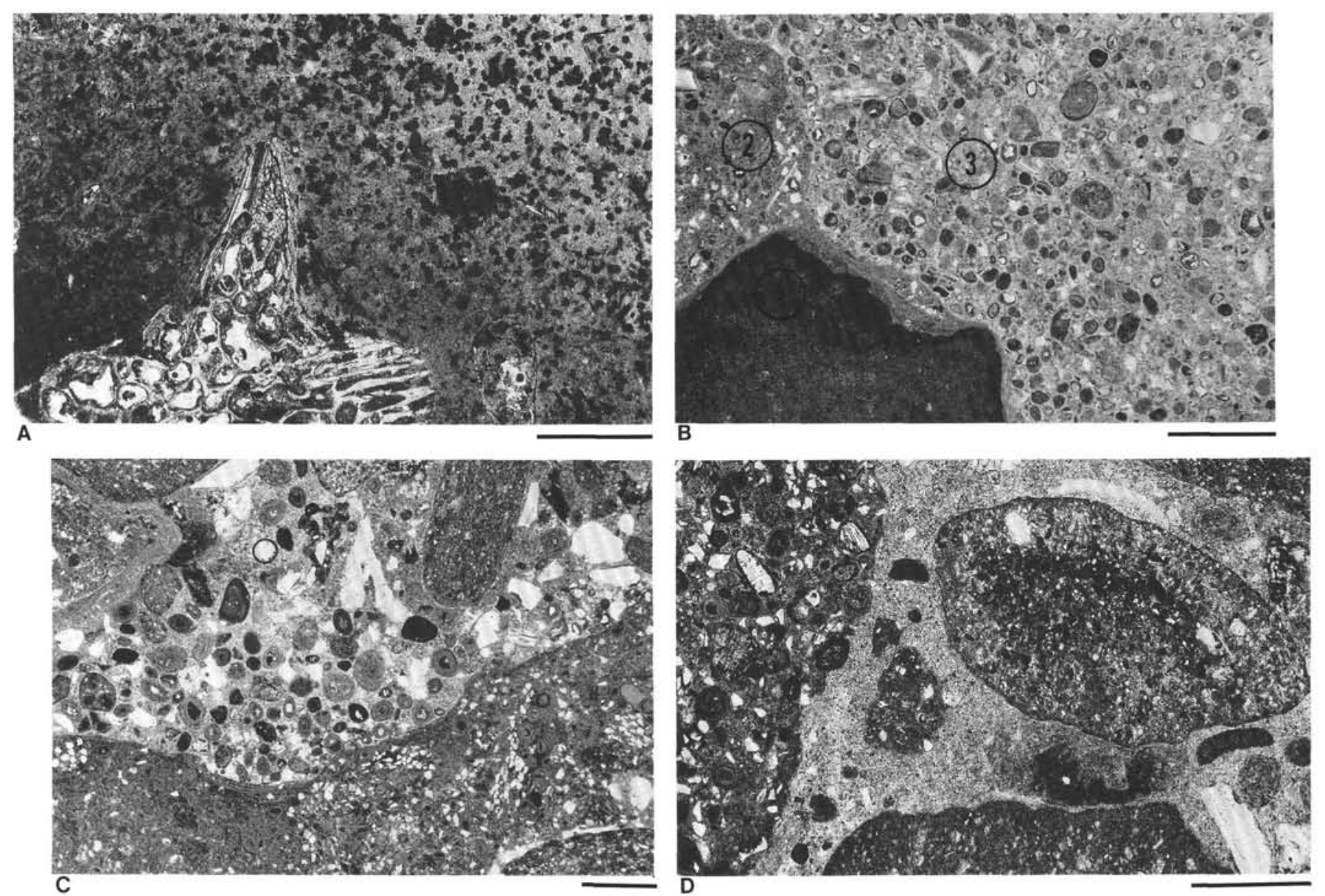

Figure 27. Photomicrographs of D-phosphate nodules from conglomerates. All micrographs are plane light; scale bars equal $1 \mathrm{~mm}$. A. Phosphatized diatom mud nucleated around bone fragment; dark patches are clots of organic matter and pyrite (Sample 112-680A-10H-4, 75-77 $\mathrm{cm}$, Pliocene). B. Three generations of phosphatic cementation in a D-phosphate nodule. Generation 1 is dark phosphatized diatom mud, generation 2 is a phosphatized sandy mud with an interstitial cement, and generation 3 is a well-sorted P-phosphatic sandstone, with a fringing cement and abundant coated grains, fish debris, and lesser amounts of siliciclastic grains. The conglomerate in which this nodule occurs is associated with an unconformity separating the Miocene and Pliocene (Sample 112-679D-1H -1, 18-19 cm). C. Phosphatized muddy sand with interstitial CFA cement at bottom is overlain by a cemented phosphatic conglomerate containing fish debris, peloids, coated grains and rounded intraclasts of the layer at the bottom (Sample 112-680A-7H-1, 63-66 cm, Pliocene). D. Detail of phosphatic conglomerate shown in C.

reworking of previously cemented nodules and hardgrounds. The integrated effects of slow sedimentation and high energy were episodically strong enough so that cycles of phosphatization (CFA precipitation)-burial-exhumation-reburial-rephosphatization occurred repeatedly, producing distinctive Dphosphate layers to mark hiatuses of varying durations.

\section{SPATIAL AND TEMPORAL DISTRIBUTION OF PHOSPHATES ALONG THE PERU MARGIN}

\section{Summary of Occurrences}

Figures 1 and 2 show the geographic and stratigraphic distribution of phosphates recovered during Leg 112. Phosphates occur in sediments as old as middle Miocene, but are most abundant in Pliocene and Quaternary upwelling sequences. Spatially, the phosphates are present in shelf and upper-slope sites (Sites 679, 680, 681, 684, 686, and 687), but are absent at the deeper slope sites (Sites 682, 683, and 685, all at present water depths below $2000 \mathrm{~m}$ ) that had high sedimentation rates and substantial terrigenous clastic influx, and that lie well below today's oxygen-minimum zone. As mentioned previously, Site 688 , which lies on the lower slope at a depth of $3826 \mathrm{~m}$, contains minor phosphate that was apparently transported from shelf depths by slumping or redeposition.

The major phosphate-bearing sites (Figs. 1 and 2, Table 1) can be divided into two categories: (1) shallow shelf sites with modern water depths between about 150 and $300 \mathrm{~m}$, near the upper boundary of the present oxygen-minimum zone (Sites 680, 681, 687); and (2) outer-shelf/upper-slope sites lying in the oxygen-minimum zone at depths of 425 to $450 \mathrm{~m}(679,684,687)$. Whereas D-phosphates are present in Quaternary and most Pliocene sequences at all six sites (the Pliocene at Site 686 was not reached by drilling), F-phosphates are most abundant in the deeper water, outer-shelf/ upper-slope sites. One possible explanation is that F-phosphates formed preferentially at localities more persistently within the oxygen-minimum zone, whereas the shallow shelf sites were periodically above this zone. Alternatively, Fphosphates may have been eroded and been destroyed or else transformed into P- and D-phosphates by bottom currents at the shallower sites, especially during lowstands of sea level. D-phosphates, though present at all six sites, are more abundant at the shallow shelf sites because these experienced more frequent episodes of reworking. P-phosphates are most abundant at Site 684 in the Trujillo Basin, 

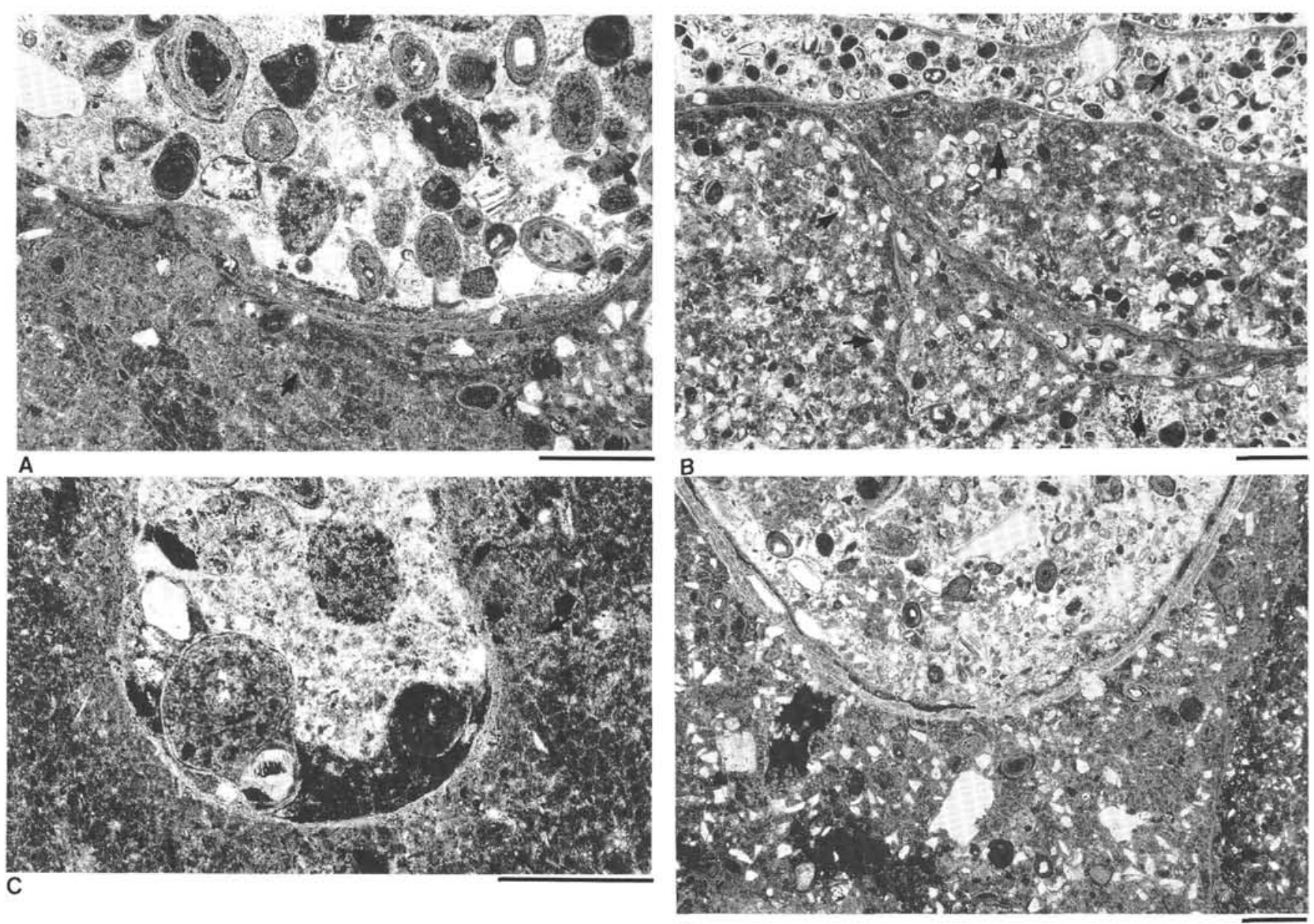

D

Figure 28. Photomicrographs of laminated phosphatic coatings in D-phosphate nodules from conglomerates. All micrographs are plane light; scale bars equal $0.5 \mathrm{~mm}$. A. Arrow indicates laminated phosphatic crust at the boundary between two generations of phosphatically cemented sediment; smaller scale view of this contact is seen in Figure 27C (Sample 112-680A-7H-1, 63-66 cm, Pliocene). B. Five laminated phosphatic crusts, shown by arrows, indicate episodic phosphatization (Sample 112-679A-7H-1, 21-27 cm, Holocene). C. Thin phosphatic crust (arrow) lines boring into a D-phosphate nodule that has a dark interstitial CFA cement; the boring is filled with a later generation of phosphatic sediment showing a geopetal fabric, with a phosphatized mud floor overlain by matrix-free P-phosphatic sand with a fringing CFA cement (Sample 112-680B-7H-3, 86-88 cm, Pliocene). D. Detail of phosphatic crust lining a large boring, possibly a bivalve boring; note that some small siliciclastic grains are cemented into the crust (Sample 112-680A-7H-1, 63-66 cm, Pliocene).

perhaps due to more persistent winnowing in this slowly subsided basin.

No correlations of individual phosphate beds could be made among the individual drilling sites. The upper $50 \mathrm{~m}$ or so of sediment at most sites contains the highest density of phosphatic layers (Fig. 2). Phosphates in general may be most abundant in Quaternary sediments, as compared to Pliocene and Miocene sequences. The Pliocene sequence is much more phosphatic than the Miocene, and Coring during Leg 112 recovered no pre-middle Miocene phosphates. This suggests that major phosphogenesis occurred primarily during the past $2 \mathrm{Ma}$, during the intensification of oceanic circulation that accompanied Pleistocene glaciation. However, this must be confirmed by more precise age dating; in addition, the recovery of Miocene and older sediments during Leg 112 was poor because of technical drilling difficulties, poor core recovery (cf. Fig. 2), and a lack of drilling time.

\section{Phosphates and Laminated-Burrowed Cycles}

Alternations of laminated and burrowed diatom muds are present in all of the shelf and upper-slope sites drilled during Leg 112 and record fluctuations in the oxygen content of bottom waters. Unburrowed laminated muds reflect deposition beneath oxygen-poor waters that prevented colonization of the seafloor by a burrowing infauna; along the Peru margin, such sediments indicate sedimentation in the oxygen-minimum zone. At the opposite extreme, burrowed, massive (structureless) sediments indicate normal or near-normal oxygen levels (Savdra and Bottjer, 1986). Thus, interbedded laminated and burrowed diatom muds are a record of shifts in the position of the oxygen minimum some relative to the seafloor.

The best-developed record of fluctuations of this kind was recovered from the Quaternary of Site 686, where packets, tens of meters thick, of predominantly.laminated diatom mud and predominantly burrowed mud are interbedded (Fig. 33). A preliminary interpretation is that the mainly laminated intervals formed during highstands of sea level and an expanded oxygen-minimum zone on the Peru shelf, whereas the burrowed intervals were deposited above the oxygen-minimum zone during lowstands of sea level and seaward retreat of the oxygen-minimum zone (Shipboard Scientific Party, 1988), though the record is complicated by the presence of unconformities. Phosphates of all kinds tend to be most abundant in the predominantly laminated intervals (Fig. 2), which are 


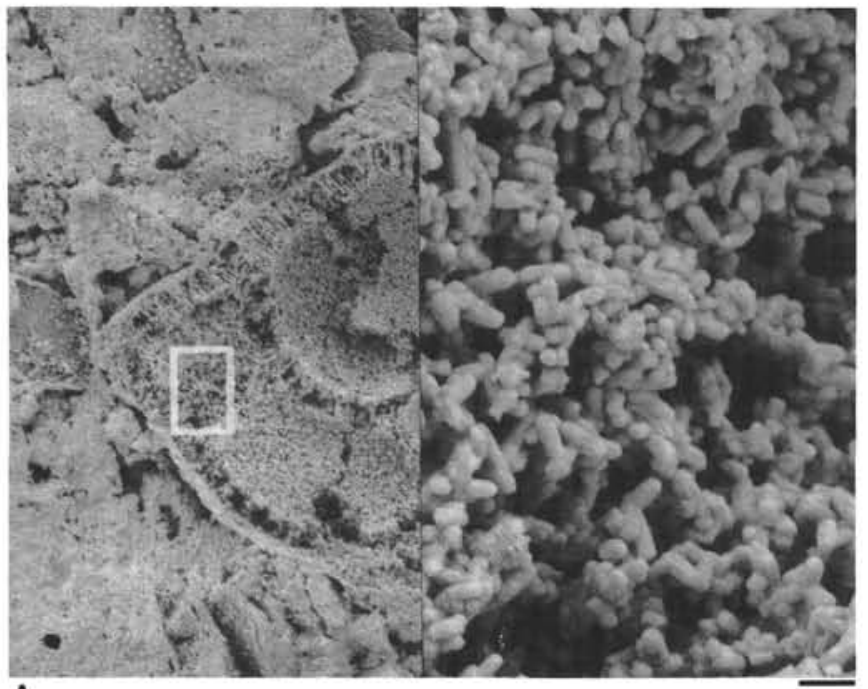

A

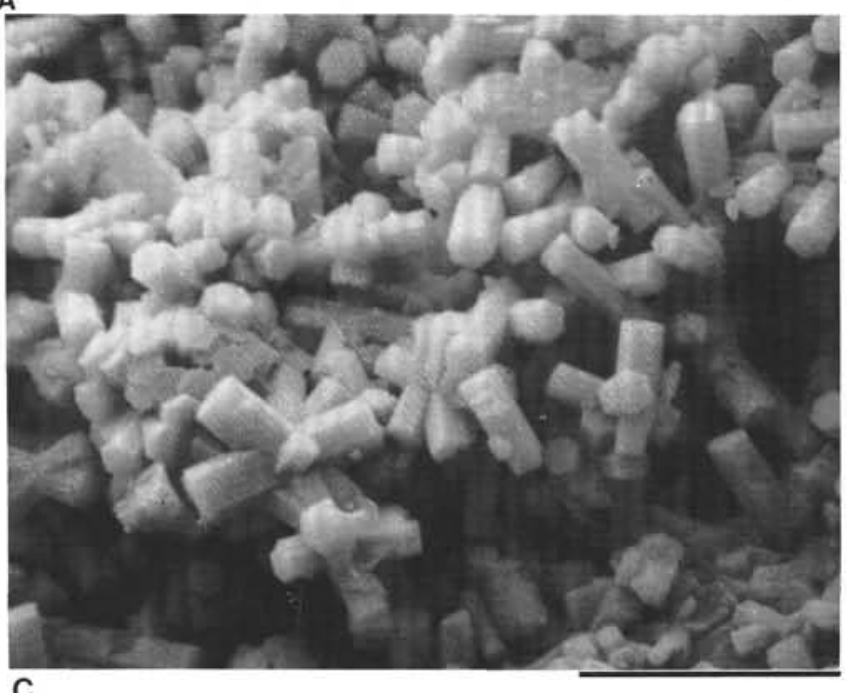

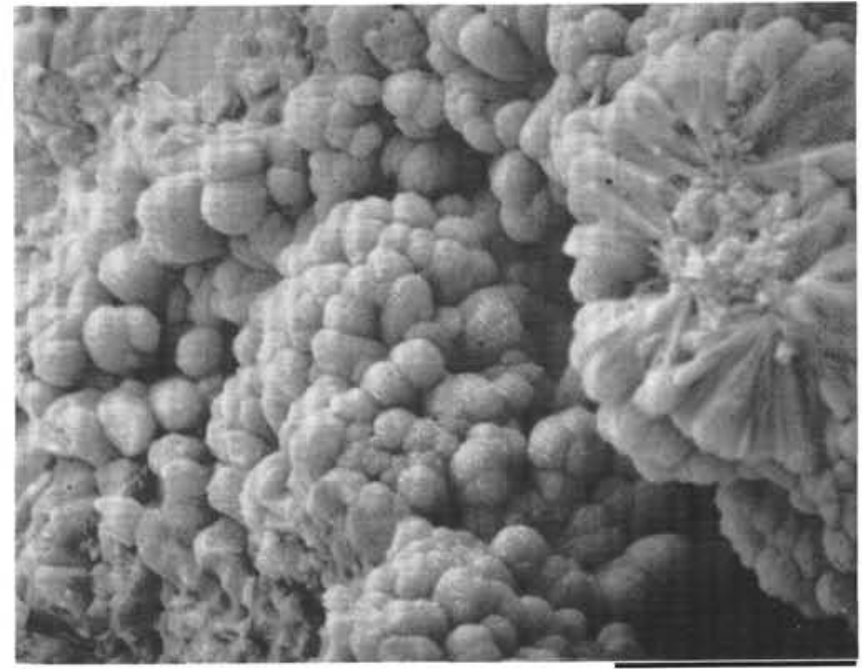

B

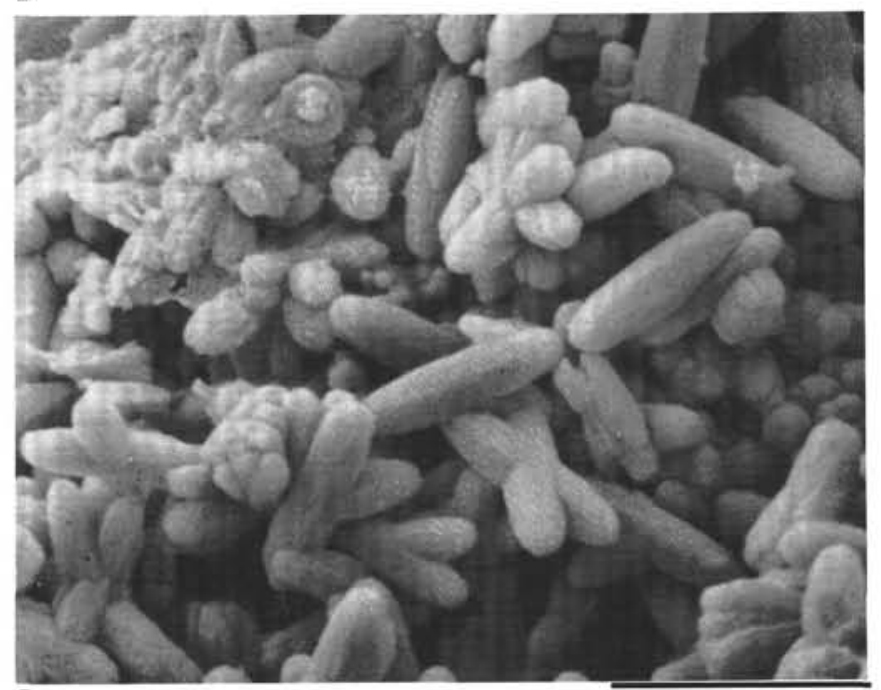

D

Figure 29. Scanning electron micrographs of cements in D-phosphate nodules. Scale bars equal $5 \mu \mathrm{m}$. A. Void-filling fringing CFA cement crystallites line the chambers of a foraminiferal test; outlined area on the left is shown enlarged at right (Sample 112-679B-2H-2, 63-65 cm, Quaternary). B. Shown here are two distinct fabrics in a fringing CFA cement. On the left are globular structures composed of CFA, at right is a rosette of acicular CFA crystallites (Sample 112-679B-6H-1, 62-63 cm, Quaternary). C. Euhedral crystallites, including numerous twinned crystallites, in a fringing cement (cf. Fig. 28B; Sample 112-679A-0-1, 21-27 cm), Holocene. D. Ellipsoidal structures with a few globular structures in a fringing cement (Sample 112-679B-6H-1, 62-63, Quaternary).

typically also the most carbon-rich intervals. In turn, this suggests that Quaternary phosphogenesis was perhaps most prevalent during warm interglacial periods, a proposal advanced earlier by Burnett (1980) on the basis of uranium-series dating of dredged phosphate nodules.

Superimposed on these thicker laminated-burrowed cycles are alternations of laminated and burrowed intervals at smaller scales, ranging from decimeters to a few meters and recording much shorter term fluctuations in oxygen levels. Figure 34 portrays some of these small-scale alternations within a predominantly laminated interval at the top of Hole 686A. Note that F-phosphates occur mostly in laminated diatom muds, whereas D-phosphates, with a few exceptions, occur mostly in burrowed or slightly burrowed muds. Thus, F-phosphates, as noted previously, formed preferentially in sediments deposited within the oxygen-minimum zone. In contrast, D-phosphates at Site 686 formed most often during what were apparently brief intervals of normal or near-normal oxygen levels and higher-than-normal energy levels, perhaps associated with short-term decreases in sea level, changes in the position of the oxygen-minimum zone, and increases in the strength of poleward-flowing bottom currents (cf. Reimers and Suess, 1983).

Characteristics of more substantial (i.e., longer term) hiatuses and condensed sections encountered during Leg 112 include scoured surfaces, thick siliciclastic layers having abraded shell fragments, and well-developed, large burrow systems (Suess, von Huene, et al., 1988). Where phosphates are associated with these pronounced unconformities, they are usually D-nodule gravels or P-phosphatic sands (e.g., Fig. 12).

\section{CONCLUSIONS}

Results from Leg 112 show that phosphogenesis along the Peru margin was complex and produced different kinds of phosphatic sediments. These sediments record fluctuating energy levels and varied periods during which the normal, 


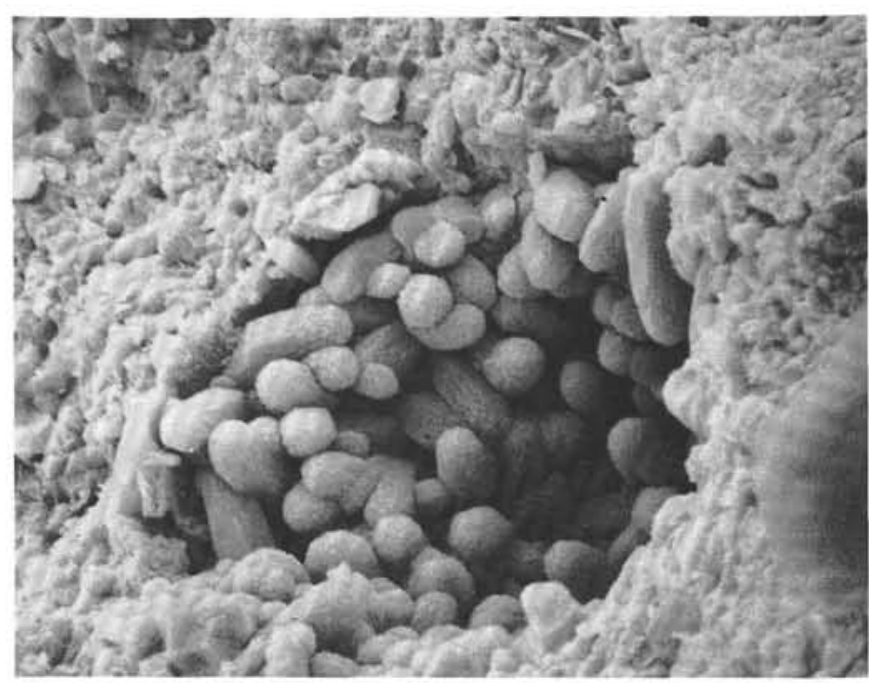

A

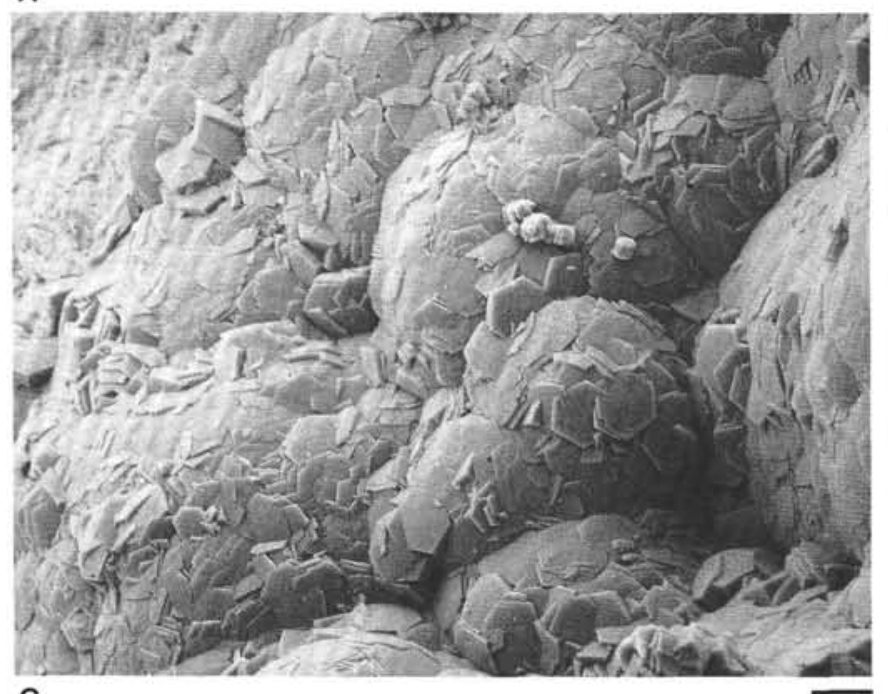

C

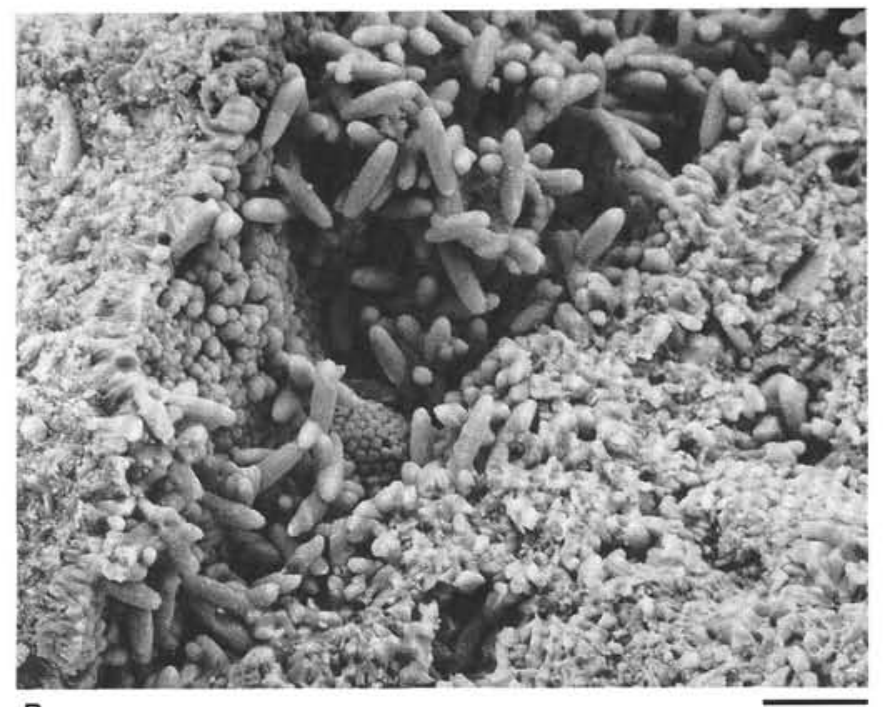

B

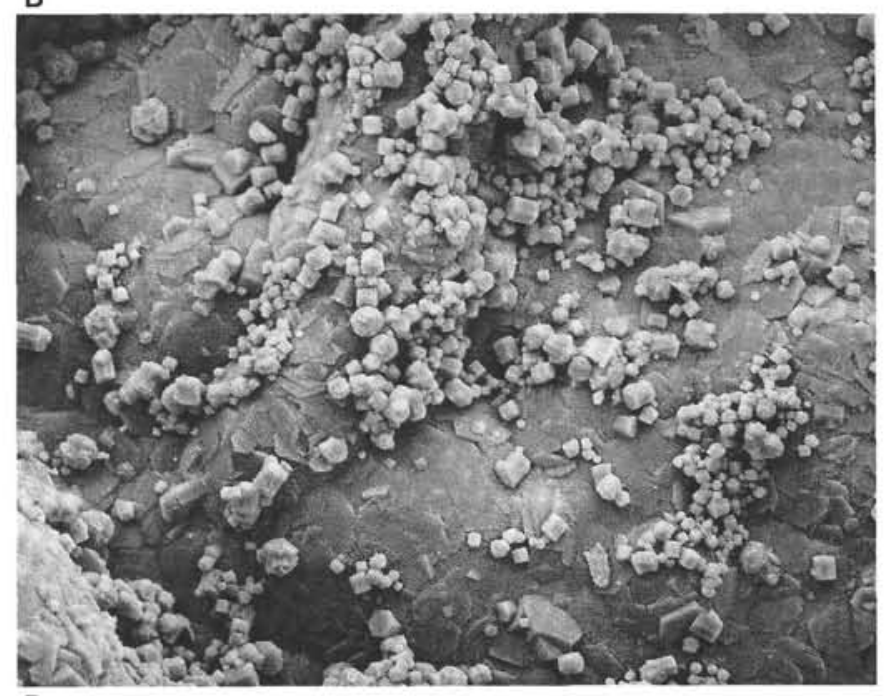

Figure 30. Scanning electron micrographs of fringing CFA cements in a D-phosphate nodule of Quaternary age (Sample 112-679B-6H-1, 62-63 $\mathrm{cm}$; scale bars equal $5 \mu \mathrm{m}$ ). A. Globular and ellipsoidal structures lining a spherical void, probably a microfossil chamber. B. Globular and ellipsoidal structures line the edges of an elongate void that extends from lower left to upper right. Note the compact interstitial cement having markedly different fabric in the areas to the left and right of the void. C. Platy hexagonal CFA crystallites covering the external surfaces of phosphatic peloidal grains. D. Platy hexagonal CFA crystallites rimming grain surfaces are overlain by a later generation of stubby, euhedral to subhedral CFA crystallites.

low-energy deposition of diatom muds was interrupted on the shelf and upper slope of the Peru margin. The apparent abundance of phosphatic sediments of Quaternary age, compared with Pliocene and Miocene sediments, may be a reflection of large fluctuations in variables that control phosphogenesis (e.g., position of sea level, energy level, intensity of upwelling, extent of the oxygen-minimum zone) during times of pronounced glacial/interglacial cycles.

The stratigraphic record of phosphogenesis provided by Leg 112 suggests that the Peru margin constitutes an approximate analog to some, but not all, ancient phosphate-bearing sequences. Not surprisingly, it most closely resembles Miocene siliceous and phosphatic sequences in onshore Peru (Cheney et al., 1979; Dunbar and Baker, 1988) and California (Pisciotto and Garrison, 1981; Garrison et al., 1987), where upwelling associated with eastern boundary currents was probably the same as today, and where sedimentation took place on narrow shelves or in small, deep basins. This record is similar also to the Permian Phosphoria Formation in that its phosphatic sediments are spatially related to siliceous deposits, but the Phosphoria phosphorites grade laterally into widespread platform carbonates (Sheldon, 1963), for which there are no counterparts in Peru. Similarly, voluminous Upper Cretaceous phosphorites in the Middle East (Reiss, 1988; Glenn and Arthur, 1988b) and Neogene phosphorites in the southeastern U.S. (Riggs, 1984) lack extensive associated siliceous deposits and instead are interbedded with carbonates or glauconitic rocks.

\section{ACKNOWLEDGMENTS}

Financial support for this work was provided by grants from the U.S. Scientific Advisory Committee (USSAC) and the National Science Foundation (OCE 88-12329). For technical assistance we are grateful to Eugenio Gonzales, Michael Knappertsbusch, and especially Dallilah El-Sabbagh. Evelyn Hegemier drafted several of the figures, and Karl Follmi and Kurt Grimm provided helpful reviews of an earlier draft of this manuscript. To our fellow scientists on Leg 112 and to the ship and drilling crew on board the JOIDES Resolution we express our gratitude for their helpfulness and cooperation. 

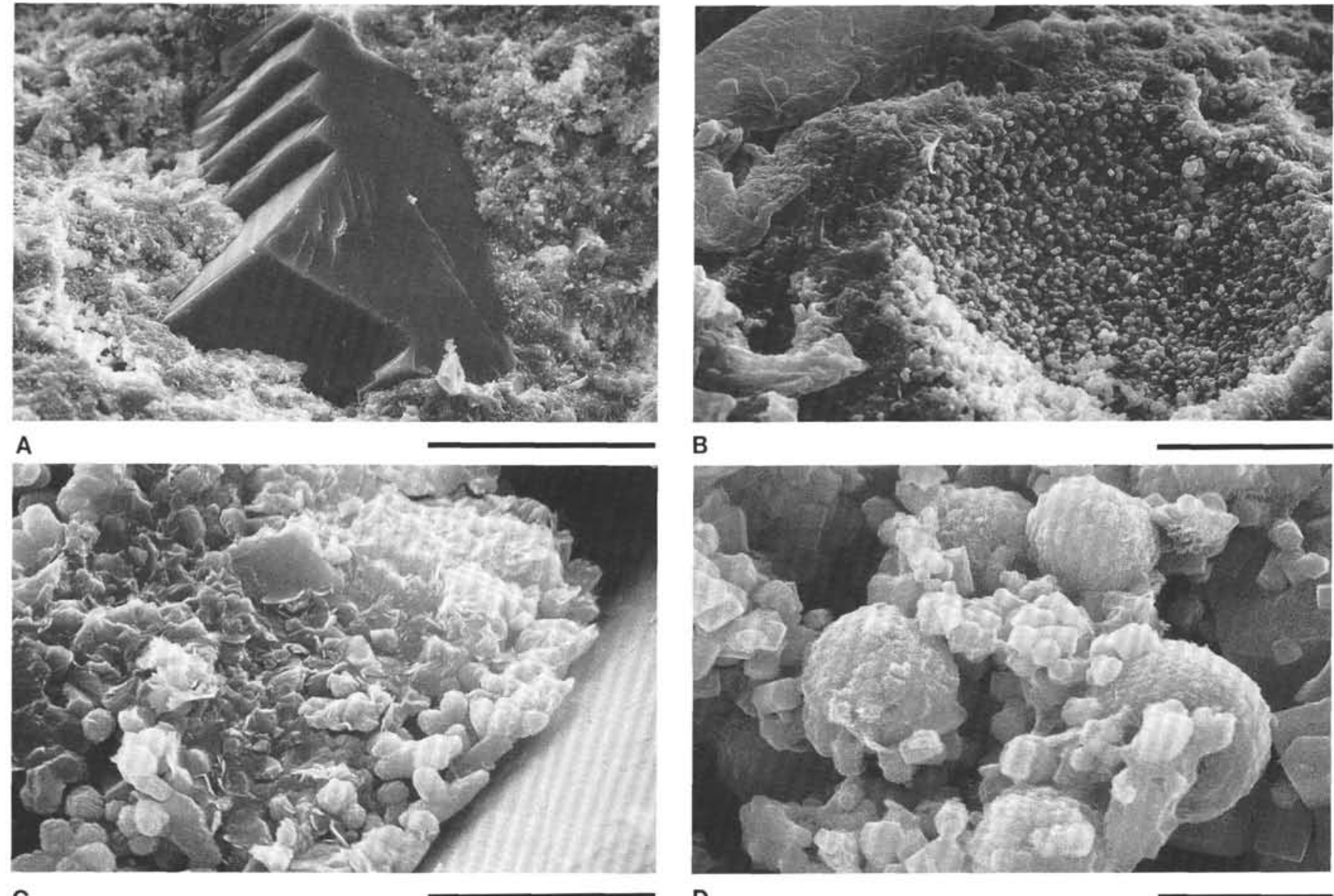

B

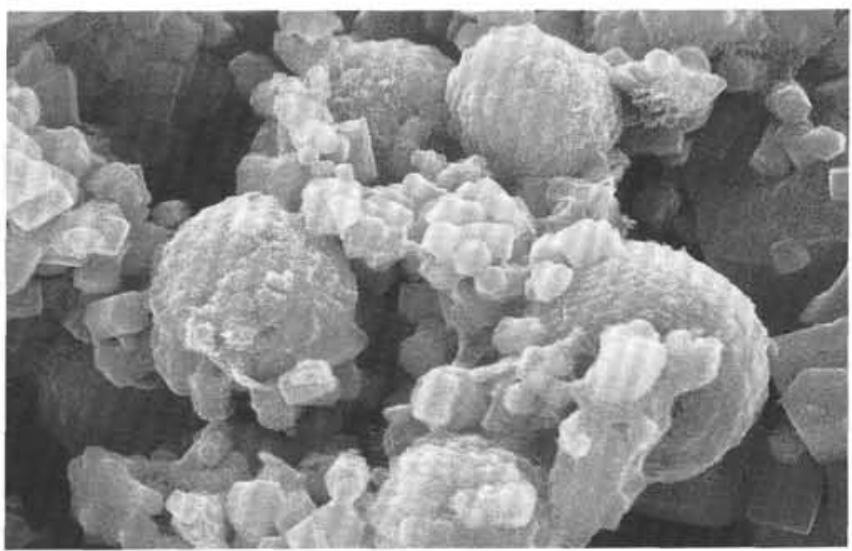

C

D

Figure 31. Scanning electron micrographs of CFA cements in D-phosphates. A. Authigenic dolomite crystal in matrix of interstitial CFA cement of a Quaternary hardground (Sample 112-686A-2H-2, 57-59 cm; scale bar equals $50 \mu \mathrm{m}$ ). B. Contrast between fringing CFA cement lining the microfossil cavity in the center and the compact interstitial cement in the surrounding areas. Quaternary hardground, same sample as A.; scale bar $=20 \mu \mathrm{m}$. C. Detail of contact shown in A between dolomite crystal and interstitial CFA cement; scale bar equals $5 \mu \mathrm{m}$. D. Globular structures overlain by stubby euhedral CFA crystallites in a fringing cement of a Pliocene D-phosphate nodule; scale bar equals $1 \mu \mathrm{m}$. (Sample $112-680 \mathrm{~A}-7 \mathrm{H}-1,63-66 \mathrm{~cm})$.

\section{REFERENCES}

Atlas, E. L., 1971. Phosphate equilibria in seawater and interstitial waters [PhD dissert.]. Oregon State University, Corvallis.

Baker, K. B., and Burnett, W. C., 1988. Distribution, texture, and composition of modern phosphate pellets in Peru shelf muds. Mar. Geol., 80:136-214.

Baturin, G. N., Merkulova, K. I., and Chalov, P. I., 1972. Radiometric evidence for recent information of phosphatic nodules in marine shelf sediments. Mar. Geol., 113:37-41.

Bentor, Y. K., 1980. Phosphorites-the unsolved problems. In Bentor, Y. K. (Ed.), Phosphorites-Geochemistry, Occurrence, Genesis. Soc. Econ. Paleont. Mineral. Spec. Pub., 29:8-18.

Burnett, W. C., 1977. Geochemistry and origin of phosphorite deposits from off Peru and Chile. Geol. Soc. Am. Bull., 88:813-823.

1980. Apatite-glauconite associations off Peru and Chile: paleoceanographic implications. J. Geol. Soc. (London), 137:767764.

Burnett, W. C., Veeh, H. H., and Soutar, A., 1980. U-series, oceanographic and sedimentary evidence in support of recent formation of phosphate nodules. In Bentor, Y. K. (Ed.), Marine Phosphates-Geochemistry, Occurrence, Genesis. Soc. Econ. Paleont. Mineral. Spec. Pub., 29:61-71.

Burnett, W. C., Baker, K. B., Chin, P. A., McCabe, W., and Ditchburn, R., 1988. Uranium-series and AMS ${ }^{14} \mathrm{C}$ studies of modern phosphatic pellets from Peru shelf muds. Mar. Geol., 80:215-230.
Burnett, W. C., Beers, M. J., and Roe, K. K., 1982. Growth rates of phosphate nodules from the continental margin off Peru. Science, 215:1616-1617.

Burnett, W. C., and Froelich, P. N. (Eds.), 1988a. The origin of marine phosphorite. The results of the R. V. Robert D. Conrad Cruise 23-06 to the Peru Shelf. Mar. Geol., 80:181-343. 1988b. Preface. Mar. Geol., 80:III-IV.

Burnett, W. C., and Veeh, H. H., 1977. Uranium-series disequilibrium studies in phosphorite nodules from the west coast of South Africa. Geochim. Cosmochim. Acta, 41:755-764.

Cheney, T. M., McClellan, G. H., and Montgomery, E. S., 1979. Sechura phosphate deposits, their stratigraphy, origin and composition. Econ. Geol., 74:232-259.

Dahanayake, K., and Krumbein, W.E., 1985. Ultrastructure of a microbial mat-generated phosphorite. Miner. Deposits, 20:260265.

Dunbar, R. B., and Baker, P. A. (Eds.), 1988. Cenozoic Geology of the Pisco Basin. Int. Geol. Correl. Program 156, Guidebook, Lima, Peru, May 16-25, 1988, 1-254.

Froelich, P. N., Arthur, M. A., Burnett, W. C., Deakin, M., Hensley, V., Jahnke, R., Kaul, L., Kim, K.-H., Soutar, A., and Vathakanon, C., 1988. Early diagenesis of organic matter in Peru continental margin sediments: phosphorite precipitation. Mar. Geol., 80:309-343.

Froelich, P. N., Kim, K. H., Jahnke, R., Burnett, W. C., Soutar, A., and Deakin, M., 1983. Pore water fluoride in Peru continental 


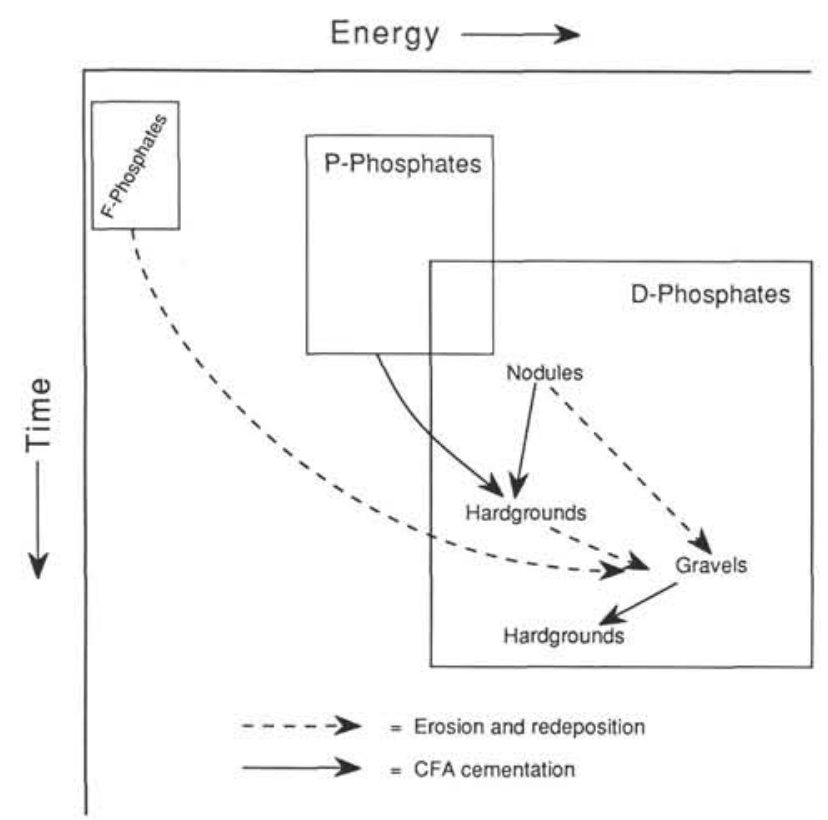

Figure 32. Schematic portrayal of time and energy relationships of the different kind of phosphates in Peru margin upwelling sediments. Shown also are transitions among the three kinds of phosphates resulting from reworking and cementation on or near the seafloor.

margin sediments: uptake from seawater. Geochim. Cosmochim. Acta, 47:1605-1612.

Garrison, R. E., Kastner, M., and Kolodny, Y., 1987. Phosphorites and phosphatic rocks in the Monterey Formation and related Miocene units, coastal California. In Ingersol, R. V., and Ernst, W. G. (Eds.), Cenozoic Basin Development in Coastal California, Vol. 6 of the Rubey Volumes: Englewood Cliffs, NJ (PrenticeHall), 348-381.

Gerdes, G., and Krumbein, W. E., 1987. Biolaminated Deposits. Lecture Notes in Earth Sciences: New York-Berlin-Heidelberg (Springer-Verlag), 1-183.

Glenn, C. R., and Arthur, M. A., 1988a. Petrology and major element geochemistry of Peru margin phosphorites and associated diagenetic minerals: authigenesis in modern organic-rich sediments. Mar. Geol., 80:231-268.

, in press. Sedimentology and origin of Upper Cretaceous phosphorites, glauconites and associated strata, Egypt. Sedimentology.

Glenn. C. R., Arthur, M. A., Yeh, H.-W., and Burnett, W. C., 1988. Carbon isotopic composition and lattice-bound carbonate of PeruChile margin phosphorites. Mar. Geol., 80:287-308.

Heggie, D. T., O'Brien, G. W., Blanks, A., Reimers, C. E., Burnett, W., and McArthur, J., 1987. East Australian modern marine phosphorites: geochemical cycling through pore waters. EOS, $88: 1711$.

Heggie, D. T., O'Brien, G. W., Reimers, C., Burnett, W. C., McArthur, J. M., Blanks, A., Skyring, G. W., Herezeg, A., Milnes, A. R., Riggs, S. R., Cook, P. J., Moriarty, D., and Hill, P. J., in press. Iron-phosphorous cycling, sediment mixing, and the formation of modern marine phosphorites on the east Australian continental margin. Nature.

Kim, K. H., and Burnett, W. C., 1988. Accumulation and biological mixing of Peru margin sediments. Mar. Geol., 80:1810-194.

Krajewski, K. P., 1984. Early diagenetic phosphate cements in the Albian condensed glauconitic limestone of the Tatra Mountains. Sedimentology, 31:443-470.

Jahnke, R. A., Emerson, R. S., Roe, K. K., and Burnett, W. C., 1983. The present-day formation of apatite in Mexican continental margin sediments. Geochim. Cosmochim. Acta, 47:259-288.

Lucas, J., and Prevot, L., 1984. Synthése de l'apatite par voie bacterienne a partir de matiére organique phosphatèe et de divers carbonates de calcium dans eaux douce et marine naturelles. Chem. Geol., 42:101-118.
1985. The synthesis of apatite by bacterial activity: mechanism. Sci. Geol. Mem., 177:83-92.

Manheim, F., Rowe, G. T., and Jipa, D., 1975. Marine phosphorite off Peru. J. Sediment. Petrol., 45:243-251.

O'Brien, G. W., Harris, J. R., Milnes, A. R., and Veeh, H. H., 1981. Bacterial origin of East Australian continental margin phosphorites. Nature, 294:442-444.

O'Brien, G., and Heggie, D., 1988. East Australian continental margin phosphorites. EOS, 89:2.

Pisciotto, K. A., and Garrison, R. E., 1981. Lithofacies and depositional environments of the Monterey Formation, California. Pacific Sect., Soc. Econ. Paleontol. Mineral. Spec. Pub., 97-122.

Reimers, C. E., Kastner, M., and Garrison, R. E., in press. The role of bacterial mats in phosphate mineralization with particular reference to the Monterey Formation. In Burnett, W. C., and Riggs, S. (Eds.), Modern and Neogene Phosphorites: Cambridge (Cambridge Univ. Press).

Reimers, C. E., and Suess, E., 1983. Spatial and temporal patterns of organic matter accumulation on the Peru continental margin. In Seuss, E., and Theide, J., (Eds.), Coastal Upwelling-Its Sedimentary Record, Part B.: Sedimentary Records of Ancient Coastal Upwelling: New York (Plenum), 311-348.

Reiss, Z., 1988. Assemblages from a Senonian high-productivity sea. Rev. Paleobiolgie, Spec. Vol., 2:323-332.

Riggs, S. R., 1984. Paleoceanographic model of Neogene phosphorite deposition, U.S. Atlantic continental margin. Science, 223:123131.

Savdra, C. E., and Bottjer, D. J., 1988. Trace-fossil model for reconstruction of paleo-oxygenation in bottom waters. Geology, 14:3-8.

Schuffert, J. D., Kastner, M., and Jahnke, R. A., 1987. Recent apatite formation off southern Baja California. EOS, 88:1711.

Shaffer, G., 1988. Phosphate pumps and shuttles in the Black Sea. Nature, 321:515-517.

Sheldon, R. P., 1983. Physical Stratigraphy and mineral resources of Permian rocks in western Wyoming. U.S. Geol. Surv. Prof. Pap., 313D:49-273.

Shipboard Scientific Party, 1988. Introduction, objectives, and principal results, Leg 112, Peru continental margin. In Suess, E., von Huene, R., et al., Proc. ODP, Init. Repts., 112: College Station, TX (Ocean Drilling Program), 5-23.

Soudry, D., 1987. Ultra-fine structures and genesis of the Campanian Negev high-grade phosphorites (southern Israel). Sedimentology, $34: 841-880$

Soudry, D., and Champetier, Y., 1983. Microbial processes in the Negev phosphorites (southern Israel). Sedimentology, 30:411423 .

Soudry, D., and Lewy, Z., 1988. Microbially influenced formation of phosphate nodules and megafossil molds (Negev, southern Israel). Palaeogeogr., Palaeoclimatol., Palaeoecol., 84:15-34.

Soudry, D., and Nathan, Y., 1980. Phosphate peloids from the Negev phosphorites. J. Geol. Soc. (London), 137:749-755.

Suess, E., 1981. Phosphate regeneration from sediments of the Peru continental margin by dissolution of fish debris. Geochim. Cosmochim. Acta, 45:577-588.

Suess, E., von Huene, R., et al., 1988. Proc. ODP. Init. Repts., 112: College Station, TX (Ocean Drilling Program).

Thornburg, T. M. and Kulm, L. D., 1981. Sedimentary basins of the Peru continental margin: structure, stratigraphy and Cenozoic tectonics from $6^{\circ} \mathrm{S}$ to $16^{\circ} \mathrm{S}$ latitude. In Kulm, L. K., Dymond, J., Dasch, E. J., and Hussong, D. M. (Eds.), Nazca Plate: Crustal Formation and Andean Convergence. Geol. Soc. Am. Mem., 154:489-508.

Van Cappellen, P., and Berner, R. A., 1988. A mathematical model for early diagenesis of phosphorus and fluorine in marine sediments: apatite precipitation. Am. J. Sci., 288:289-333.

Veeh, H. H., Burnett, W. C., and Soutar, A., 1973. Contemporary phosphorites of the continental margin off Peru. Science, 181:844845 .

Date of initial receipt: 3 November 1988

Date of acceptance: 7 August 1989

Ms 112B-145 

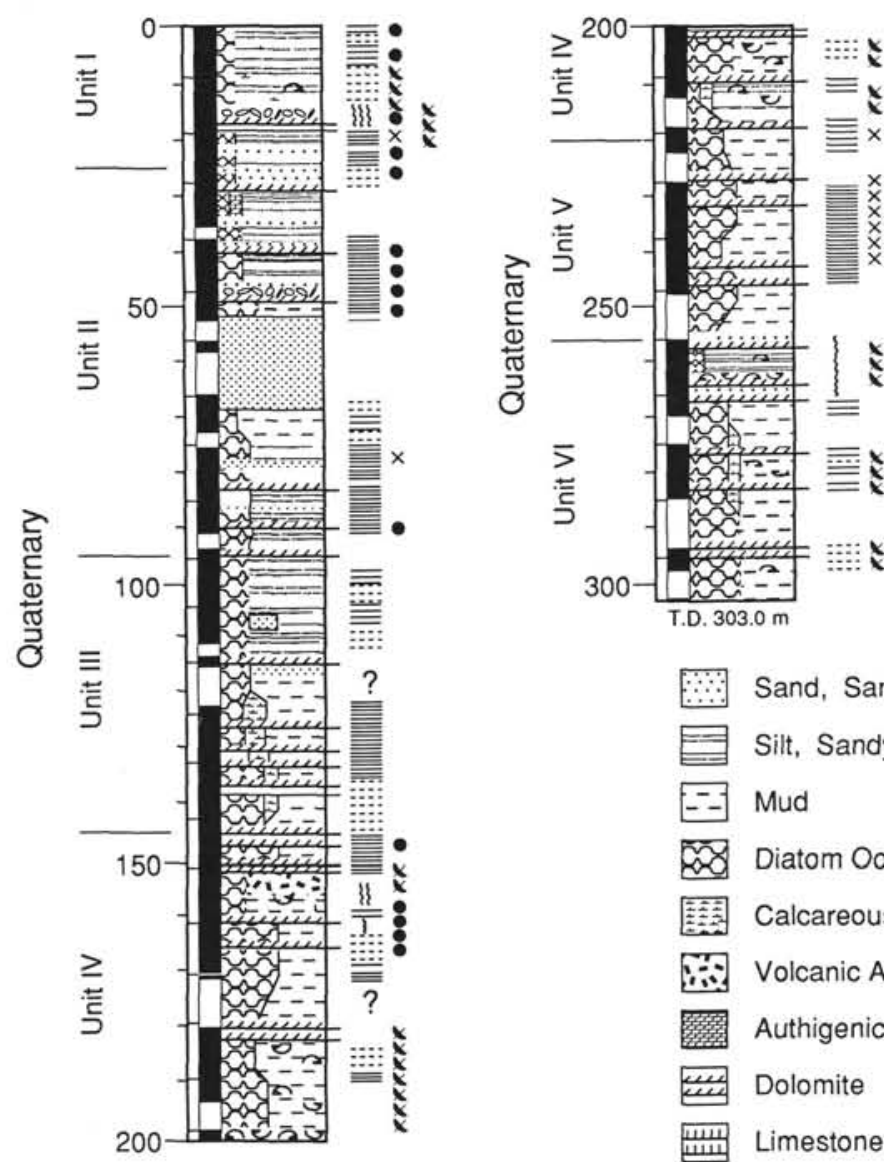

$\therefore$ Sand, Sandy Silt

Silt, Sandy Mud

$=--$ Mud

ल] Diatom Ooze

筀图 Calcareous Ooze

$\therefore$ Volcanic Ash

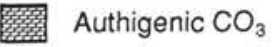

Dolomite

필 Limestone

E్ Shell Hash

Phosphates

il Bioturbation

$\times$ F-Phosphate

Lamination with

- D-Phosphate slight bioturbation Lamination

$x_{\mathbf{x}}$ Shell Fragments

Figure 33. Quaternary sediment record recovered in Hole 686B. Note alternation of laminated and massive (structureless) to burrowed diatom muds, as well as the preferential association of phosphates with laminated intervals. 


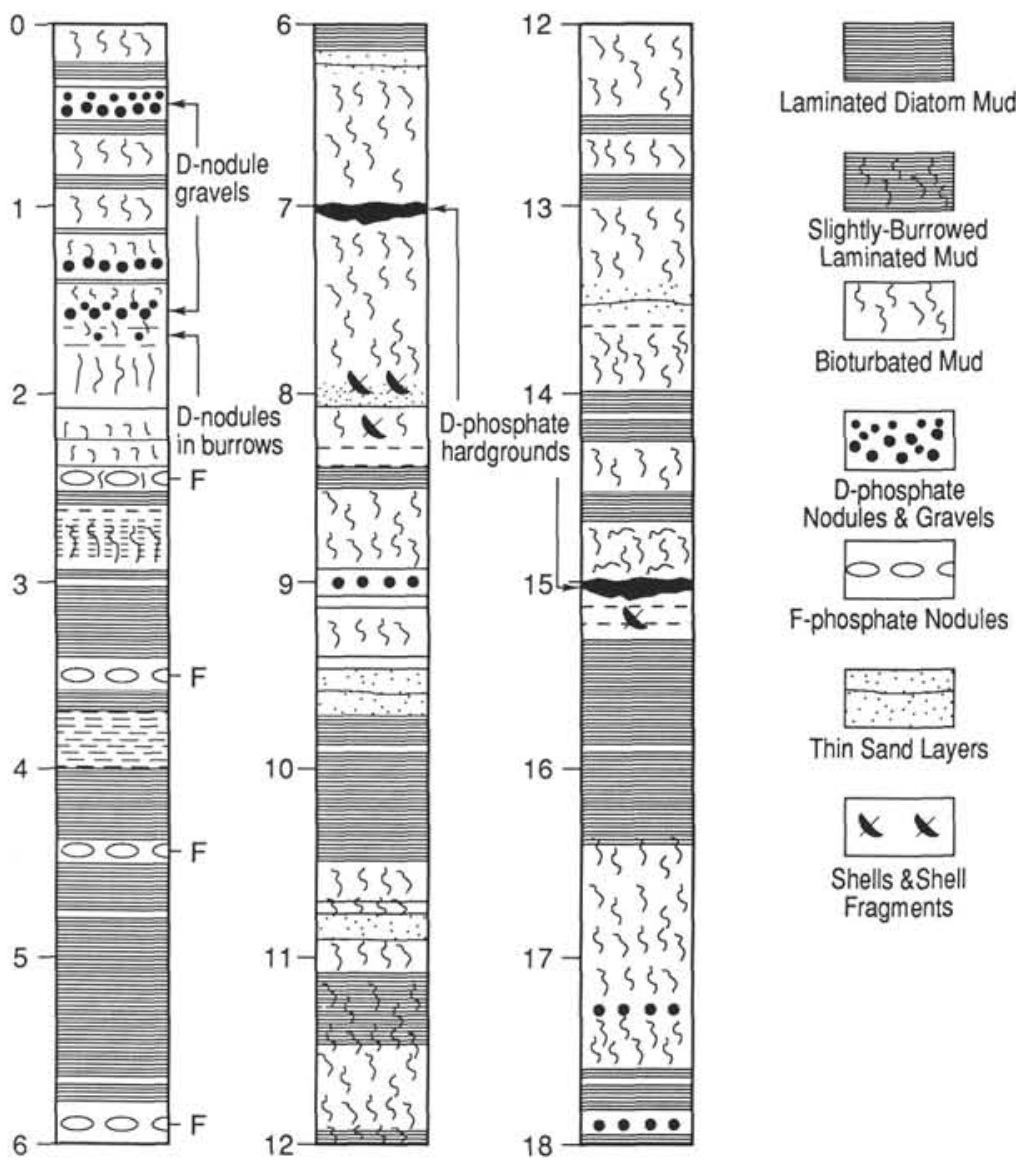

Figure 34. Detailed stratigraphic column of the upper $18 \mathrm{~m}$ of Quaternary sediment in Hole 686A (Cores $112-686 \mathrm{~A}-1 \mathrm{H}$ through $-3 \mathrm{H}$ ). This is a predominantly laminated interval, but contains thin burrowed layers that indicate short-term intervals of seafloor oxygenation and that contain most of the D-phosphates. 